\title{
HRYHORRI SKOVORODA'S THEORY ON THE INNER VOICE AND ITS APPLICATION IN HYPNOTHERAPEUTIC REST: AN EXPLORATORY CASE STUDY APPROACH
}

\section{$\Lambda$ iнда Аолан \\ TEОРІЯ ВНУТРІШНЬОГО ГОЛОСУ ГРИГОРІЯ СКОВОРОДИ ТА Ї̈̈ ЗАСТОСУВАННЯ В ГІПНОТЕРАПЕВТИЧНОМУ ВІДПОЧИНКУ: КЛІНІЧНИЙ ПІДХІД}

\section{Introduction}

The Ukrainian philosopher, Hryhorri Skovoroda $(1722-1794,1972 ; 1995)$ proposed that ultimate happiness, health and reward depend on a human being's awareness of one's inner voice and respect and implementation thereof in one's personal goals. He emphasized that every human being is a dignified person in the Creator's eyes and is constantly guided by the inner voice or the Holy Spirit. Skovoroda's theory can be considered to be highly relevant for human beings who are searching for spiritual entities in understanding themselves.

Skovoroda referred to the inner voice in a number of different contexts. Fundamentally he referred to the inner voice as the voice of God, the voice of the Creator, the Holy Spirit. Thus he developed two core propositions. Firstly he found that the human being is a spiritual entity (Scherer, 1997). Secondly, he found that the human being is capable of being influenced by "earthly dust" (Shubin, 2012) however he viewed the inner voice, the spirit, as much more powerful then external influences.

The concept of spirituality and its relationship to the inner voice is clear in Skovoroda's theory and thus spirituality will form a key concept of this literature review.

Against this background, listening to one's inner voice can be seen to be uniquely relevant to the role spirituality plays in hypnotherapeutic rest because it allows the patient to reflect inwardly without being influenced by any direct external source, such as, imposing suggestions, asking the patient questions or telling them what to do (Hlywa, 2013).

This forms the essence of my current study, where I have found after many years in clinical practice, that when patients are given the opportunity to listen to their own voice whether it be in quiet hypnotic rest (Hlywa, 2008; Kuriyama, 1968; Kleinhauz, 1991) or their own "inner dialogue", "reverie" or "contemplation", they can reflect and make their own decisions (Meilan, 2008).

It will be shown that an exploration of Skovoroda's theory on spirituality is a valuable and unique contribution to the field of hypnosis because hypnosis enhances human capacity to a great degree and thus enables human beings to reach within themselves for guidance in their path of life (Hlywa, 2013; Shubin, 2012).

This review will highlight the gap in the literature in the use of hypnotherapeutic rest in patient care. The idea of rest touches every human being at the very core of one's existence. This is evident in the universal phrase "Rest in Peace" that is often ascribed to those who have died and yet, it is this very experience that many people are striving to achieve in life! In 2011,

Copyright @ DOLAN Lynda (Australia), ДОЛАН Лінда (Австралія), 2017. 
the Australian psychiatrist, Dr. Ainslie Meares, was honoured by the City of Melbourne with a memorial plaque on a bench in Fitzroy Park, with an inscription quoted by him saying: "Sit quietly, for it is in quietness we grow".

Centuries earlier Hryhorri Skovoroda, had written on his own gravestone "The world tried to catch me but failed". He found that the locus of the inner voice is always with every human being because the human being is the temple of God (Skovoroda, 1995). In a therapeutic context, it is proposed that the role of the therapist is to create a situation where the person can be comfortable to separate their inner voice from the earthly influences upon them, such as for example, faulty learning (Hlywa, 2004).

\section{Motivation for literature review}

The current literature review has been developed with my interest in exploring how patients in my clinical psychotherapeutic practice respond positively when they are given the opportunity to be in a complete rest without any external pressures or influences telling them how to think or what to do. This is embraced in an approach to patient care where the person is able to revise their attitude towards themselves and their environment in a neutral and confidential setting and make decisions for themselves (Hlywa, 2004).

Relevant to the literature review are the key concepts of Hryhorri Skovoroda, inner voice, hypnosis and hypnotherapeutic rest. As spirituality and psychotherapy are relevant factors influencing the inner voice in hypnotherapeutic rest, they will also be included within the scope of this literature review. A review of the literature on Skovoroda's contribution to an understanding of the inner voice and his theory of spirituality will be elucidated. This will be followed by a review of the current thinking about the concepts of hypnosis, the inner voice, spirituality and psychotherapy in the context of health and clinical practice today. These concepts will then be defined and reviewed in regard to their significance for the current study.

\section{Hryhorri Skovoroda}

Hryhorri Skovoroda (1722-1794, 1972) dedicated his entire life to teach humanity to respect and obey their inner voice, which he found to be the Creator's Voice, also known as the Holy Spirit (Shubin, 2012). He has written extensively on the essence of the human being and getting to know oneself. He proposed that it is absolutely essential for the human being to understand oneself in order to understand the cosmos. He is a highly regarded Ukrainian philosopher, poet, teacher and composer. He left the materialistic world to be investigated by those who are properly trained, skilled and educated in their respective fields. However, he accentuated that the happiness of the human being will be restored with one's knowledge and respect of oneself (Bilaniuk, 1994). He emphasized that the inner voice becomes triumphant, when the person is authentic, when they follow the path that was laid by their Creator, or when a person follows a light that leads towards one's own harbor (Bahalii, 1992). He emphasized that such authenticity and personal fulfillment in life offers just reward to a person in the form of happiness (Hlywa, 2013).

Skovoroda found that happiness is the goal of life and is unattainable without the knowledge of happiness, which is naturally and authentically within every human being (Hlywa, 2013). He also found that the knowledge necessary for a happy life is always available to every human being, regardless of age or place where they live, or talent or social status. Skovoroda found that wisdom is the totality of knowledge that is necessary for happiness, and its main characteristic is usefulness. He found that a person's perfect wisdom is not knowledge of everything in the world, but to know everything that is useful to them (Zakydalsky, 1994, p.239). This wisdom is easy to obtain, as it is the "invisible face and living word of the omnipresent divine nature that thunders secretly within each man" ( $\mathrm{Za}-$ kydalsky, 1994, p.240).

Skovoroda indicated that the essence of oneself is one's spirit (Shubin, 2012). He pointed out the power and nature of the spirit and he wrote that spirituality is invisible and reveals itself in its actions (Skovoroda, 1972). Like intellect that reveals itself in human achievements and activities, Skovoroda likened the spirit to such potential natural phenomena as hurricanes, which reveals itself in the devastation as we have witnessed in nature. Thus, spirituality can be perceived as non-vectorial or lacking direction, and it is up to each individual to listen to his / her inner voice and choose the appropriate vector (Hlywa, 2013). Human beings are endowed with recognition of absolute values (which includes love and implementing this love appropriately) and therefore they have the inherent capacity to choose a vector or goal according to their 
spiritual values. It is then that the person strives to become healthy, satisfied and happy in life (Hlywa, 2013).

There are several references to Skovoroda's extensive writings and findings on the inner voice and spirituality in the Ukrainian language and a number of growing translations and commentaries in the English language (Marshall \& Bird, 1994). However there is very little written on the application of his theory in clinical practice.

Hlywa (1998; 2004; 2006; 2009) has researched and written extensively on the application of Skovoroda's theory on spirituality in understanding the essence of the human being and the process of psychotherapy and hypnotherapy. He has also written a detailed monograph on the application of Skovoroda's theory in the process of achieving health and happiness (Hlywa, 2013). In addition Hlywa (2008a; 2008b) demonstrated how Skovoroda's theory on the inner voice and spirituality could be applied in hypnotherapy and hypnotic rest.

Hlywa \& Dolan (2016) applied Skovoroda's theory on the inner voice and spirituality in the treatment of internal trauma and have highlighted with reference to several cases, how the power of the inner voice can have such a profound influence on the human psyche, leading to internal trauma or conflict, severe physiological and psychological distress. They differentiated between external and internal trauma and showed how external trauma may not necessarily require psychotherapeutic intervention but is often able to resolve with the removal of the external stressor/s affecting the person. However the authors demonstrated how internally caused spiritual violation or trauma can be more complex, erosive and often unconscious to the patient, thus requiring skilled and concentrated effort to uncover the genesis of the trauma, exposing it and applying a healing hypno-analytical process.

Although several eminent psychologists have emphasized how the process of valuing and dignifying the person, facilitates discovery of oneself and achievement of one's task in life (Van Kaam, 1966; Jung, 1974; Rogers, 1951), Skovoroda (1972) went further and proposed that every human being is endowed equally with the Creator's gifts and the voice of the Holy Spirit. This, combined with the capacity of the human being to be in touch with their absolute values, provides the person not only with freedom but also with the obligation to make their own decisions (Hlywa, 2004).

\section{The Inner voice}

It has been known and appreciated that every human being has a conscience or inner voice (Hlywa \& Dolan, 2010-2011; Kodelja, 2015). Since antiquity, this inner voice has been considered. Socrates was a philosopher of a few written words but with exemplary life that he appreciated and he led a responsible life in dialogue with himself. He, like Skovoroda, encouraged self-knowledge in everyone (Fizer, 1997). Today, Socratic dialogue has been considered in the therapeutic process (Carey \& Mullan, 2004).

Jean-Jacques Rousseau (1712-1778) spoke about the inner voice, the voice of conscience, the voice of God, however this was in the context of legality and loyalty to oneself and authorities and was known as the "natural law" of JeanJacques Rousseau (Rousseau, 1992, location 585 of 2280). Significantly, Skovoroda's reference to the inner voice is within the context of the psyche or essence of the human being.

There are several references to the inner voice of the human being in the research (Harman, 1981; 1995; Hlywa \& Dolan, 2016; Kodelja, 2015; Skovoroda, 1722-1794; 1995). There are also many philosophers and researchers who have contributed significantly to an understanding of the essence of the human being. Some of them highlight the importance of valuing and respecting the patient's inner experiences, without direct reference to the concept of the inner voice, however most of them have developed models according to their belief systems as to how the person should or should not live, behave, think or feel in order to improve themselves. In emphasizing a person-centred approach to care, these researchers have formulated comprehensive and useful approaches on how the human being should follow certain values and rules as prescribed by a particular model of treatment, religion or belief.

Some researchers provide their expert knowledge, based on empirical data, and suggest coping mechanisms and certain techniques for humans to follow in order to achieve healthy outcomes in their lives. Many of these researchers lay claim to basing their findings and theories on valid and reliable scientific data. Many of these researchers are world experts on the understanding of human beings and their theories and findings are acceptable treatment approaches. Such expert findings have become the source of scientific truth and in many countries, are accepted as the established and ethical base of evidenced-based medicine, which, according 
to the authorities, should be adhered to when treating the human being.

For example, the medical model works with diagnosis and remediation of the problem or illness according to a specific mode of treatment to remove the symptom (Engel, 2012). Thus the patient consults an expert who tells them what is wrong with them and how to fix their problem in order to become healthy and happy.

The cognitive-behaviouristic model (Beck, 2011) implies that the patient should adopt certain thoughts, behaviours and ways of remediating their problem by following a certain course of therapy with the goal of changing the behaviour. Contemporary behaviourist models (Hayes, Follett \& Linehan, 2011) have now incorporated mindfulness meditation and acceptance therapy into their model in a way that implies that the person is told to follow certain methods given to them by the therapist or some external source (e.g. verbal scripts read to the patient, tape recordings, visualisations, mantra's and other techniques) to accept their state of mind and move through their problem.

The humanistic and existential approaches emphasize understanding the inner dynamics of the personality to find out what the patient is. For example, Carl Jung (1916/2002; 1974) divided a human being on anima and animus, shadow, unconscious, preconscious and subconscious, and collective unconscious. He maintained that the fully developed and mature human being is a conglomerate of nature and nurture, its experience and influence, and in his analytical work he looked for the factors influencing the human being.

Religious approaches to counselling suggest a certain worldview or belief system and lifestyle to follow to become happy and healthy. Adrian van Kaam (1966; 1969; 1975), although being a theologian as well as philosopher, in his scientific psychological and psychotherapeutic encounter, relied largely on data obtained through the organs of perception. He said that a person will find health and happiness when they dedicate themselves to a certain goal they value greatly and live this goal fully (van Kaam, 2011).

Harman (1981, 1995) has highlighted several problems and challenges to adopting a science of human consciousness that could transform society in a positive way when such a worldview of listening to external opinion is accepted as the treatment of choice. He proposed that each human being has access to a "supraconscious, creative ... mind whose capabilities are ...unlimited" and he refers to this in the context of the "inner voice" or "inner knowing" of a "perennial wisdom" (pp. 7-8). He proposed that human beings could exercise their capacity to choose in a way that promotes good as opposed to bad choosing. He offered three conditions for reaching the true inner voice, namely:

...willingness to perceive differently ... a willingness to listen to no other voice ... (and) the willingness to join with others in defenseless bonding... (p. 11)

Tannous (1981) cautioned against Harman's proposal to listen to one's true inner voice with the faith and knowing that comes with reaching this creative, intuitive and unconscious mind, before it has been sufficiently probed and tested for evidence of the promised rewards. He also cautioned further that such belief in a supraconscious, creative potential could lead to negating a sense of individual responsibility and creative role and could lead people to being misled by a promise of blind faith in a "perennial wisdom" as a higher cultist personality.

The potential dangers as cautioned by Tannous and others can be avoided by embracing the spiritual entities that every human being is endowed with. Scott \& Bergin (2005) emphasize this in their reference to the inner voice in the context of adopting a theistic worldview, that is, a belief in God. This is in line with Skovoroda's view, which forms the basis of the current study.

Reviewing the literature it becomes clear that most therapists who utilised a theory of personality maintain, together with Carl Rogers, the now popular view that every patient has the potentiality to know what, when and how they should and could obtain health and happiness. Here we can use as an example Milton Erickson (1967; 1980a; 1980b; 1980c), who constantly warned psychotherapists not to learn anything from him but to listen and get to know their patient. Carl Jung's (2001) attitude was similar and he openly suggested spiritual and religious vitality in reviving human beings from their misery and sickness.

However, it appears that Skovoroda is one of the unique philosophers to date who went further then most, including those mentioned above, who said that one does need to look for life wisdom anywhere but appreciate their inner voice, which he maintained to be the Holy Spirit 
with which every human individual always was and is endowed by the Creator. He assured the human race of finding happiness within oneself when they are listening to their inner voice that emanates from the Creator (Hlywa, 2013; Skovoroda, 1995).

It is evident from a review of the literature that reference to the inner voice is consistently linked to the voice of the Holy Spirit, the Creator and that, which is unseen. With reference to the writings of William James (1902/1936; 2011), Scott \& Bergin (2005, p.22) refer to the concept of 'spiritual' as the "invisible phenomena associated with thoughts and feelings of enlightenment, vision, harmony with truth, transcendence, and oneness with God". With this in mind it is necessary to review the literature concerning the concept of spirituality to appreciate its fundamental role in the inner voice and hypnotherapeutic rest. An appreciation of the role of spirituality in hypnotherapeutic intervention can be more fully embraced within the context of an understanding of the history of spirituality from the perspectives of philosophy and psychology.

\section{Spirituality \\ Brief history of spirituality from the pers- pective of philosophy.}

Spirituality has been acknowledged since ancient times. From the time of man's selfawareness, attempts have been made to discover the essence of the authentic nature of the human being. It has been noted that without the spirit, the human body is a decaying corpse (Hlywa, \& Dolan, 2016; Skovoroda, 1972). Historically, it is noted that every philosopher investigating human nature has discovered the omnipotent factor known as soul (Aristotle, 384-322BC; Plato, 427-347 BC; Socrates, 469BC-399BC; St. Thomas Aquinas, 1225-1274; Thales of Miletus, 624-546BC).

Ancient Greek philosophers, although very proud of their body, structure and capacity, paid even greater attention to the human spirit, which became known as something very real but hidden in the universe. Ever since human being's selfawareness, man has been trying to find out the human being's motivational force (Aristotle, 1986, p.210). Ancient philosophers referred to this motivational force as that which makes the human being active. Aristotle paid attention to the "Immovable [or unmoved] mover" (Aristotle, 2007, p.282).
Humans continue to ask themselves the question: 'what am I?' Thales of Miletus (624546BC), who found that the invisible force within man is his motivational force, supposedly advanced the first answer to this question known to philosophy and psychological science. It is invisible and powerful and acts upon the human organism as a magnetic field (Aristotle, 1986, p.26). Thales challenged human beings to get to know themselves. Most ancient philosophers were engaged in getting to know themselves and they referred to the Latin saying, "Nosce te Ipsum" (Plato, 1956, p. 77). Max Scheler (18741928), Immanuel Kant (1958) and especially the patristic philosophers, including St Thomas of Aquinas (1225-1274) and Rene Descartes (15961650), emphasized the relationship of the spirit to human behaviour (Descartes, 1972; 1980).

Hryhorii Skovoroda (1722-1794) embraced the new philosophical trend of investigating the essence of the human being. He proposed that it is absolutely essential for the human being to understand oneself in order to understand the cosmos. He indicated that the essence of oneself is one's spirit (Shubin, 2012; Skovoroda, 1972). His contemporary German philosopher, Immanuel Kant (1724-1804), supported this trend by contributing a number of outstanding ideas in the field of spirituality and psychology. He proposed that man's psyche (soul) cannot be studied by means of experimentation and that ontological faith is the way to prove the existence of God (Kant, 1958).

Like Skovoroda, the Danish philosopher, Sören Kierkegaard (1813-1855) dedicated his entire (but short) life to acquaint himself with the human spirit but he was known for his emphasis on religiosity $(1972 ; 1974)$. However, it was the Dutch born German educated Catholic priest, Adrian van Kaam (1966; 1969; 1975; 2011), who proposed a real basis for the scientific approach to the study of human spirituality and formulated a detailed theory of spirituality in the psychotherapeutic process.

Van Kaam (1966) maintained that if the human being values something, they would dedicate themselves to their goal or task. He incorporated spirituality into the psychotherapy encounter by a process of discovering the dynamic power of the human being and emphasised self-discovery, which elevates the person to the status of a spiritual entity and shows the person the path of life. It is then that the person strives to become healthy, satisfied and happy in life. 
Van Kaam emphasized how the process of valuing and dignifying the person, facilitates discovery of oneself and achievement of one's task in life.

Brief history of spirituality from the perspective of psychology

The concept of spirituality has been excluded from the study of human behaviour with the development of the science of psychology. The scientists of human behaviour pointed out that spirituality lacks parameters in order to be scientifically investigated. Thus, it has been left outside the margins of research. Seaward (2000, p.242) pointed to this irony and noted that "if something couldn't be measured and validated scientifically, it didn't exist, and human spirituality definitely fell into this category".

In his article on stress and human spirituality, Seaward (2000) referred to Hans Selye, who described stress in terms of "The General Adaptation Syndrome" (Selye, 1956). He commented further on how, towards the end of his career, Hans Selye's perspective of stress grew when he spoke of spiritual issues, particularly meaning and purpose in one's life and yet the mechanistic framework, which so greatly influenced the start of his career, overshadowed his most important insights on stress. This is one example of many models of human functioning, which have completely ignored the presence, and influence of the spirit. Even the World Health Organization (WHO) noted, "Health care should be in the hands of those who are fully aware of and sympathetic to the spiritual dimension" (Seaward, 2000 , p. 244).

It is evident that the current view still emphasizes how humans are focused on wanting to 'see' something before they feel safe enough to alter their view of the world. The saying 'seeing is believing', is something that is particularly true of the scientific community, which is highly resistant to deviating in any way from its need to 'see' some proof before accepting any new information (Scott \& Bergin, 2005). Many scientists have dismissed the suggestion that 'the Creator' may play a role in natural phenomena because they claim that 'the Creator' cannot be seen or measured. However, by relying on observation, the knowledge acquired using the scientific method is limited to only study of the physical, as opposed to the spiritual (Jung, 1954; 2001; Kant, 1958).

History of the development of the scientific method is linked to the history of science itself.
There is evidence that ancient Egyptian astronomers, mathematicians and physicians relied on observation when drawing conclusions about how things in nature worked. Greek philosophers such as Democritus (460BC-370BC) largely regarded for his atomic theory, adopted similar views and eventually the rejection of mythological explanations became an essential part of the scientific revolution. Thales of Miletus $(624 \mathrm{BC}-546 \mathrm{BC})$ was the first to define general principles and put forward hypotheses. Plato (427BC-347BC), the prized student of Socrates (469BC-399BC), is credited with the development of deductive reasoning, which is an important step in the adoption of the scientific method. However, it was Aristotle (384BC322BC), a student studying under Plato, who formalised empiricism by his announcement that universal truths could only be reached via induction (Aristotle, 1986).

Although Aristotle $(1963 ; 1986)$ is regarded as the first psychologist, his predecessor, Socrates is known to have symbolically searched, on clear days, with a burning candle on the streets of Athens for a true human being. Socrates believed that the human being has alienated himself from his authentic nature. Socrates unfortunately did not leave much written work, however, his friend, Plato (1952) acknowledged that he was revising and teaching many of Socrates' thoughts. Plato (1952) contributed significantly to the discovery of the essence of the human psyche. He discovered the unconscious in the human psyche, referring to it as a wild beast in the human being that cannot be eliminated but only partially controlled.

Aristotle (1986) greatly valued knowledge, cognition and truth and paid special attention to the human soul. He wrote that no matter how important knowledge is, appreciation of the soul is much more precious. Aristotle is known as a vitalist (a notion opposite to the mechanistic views), as for him the soul was at the centre of life. According to Aristotle, the body is the vessel of all living. The soul presents the living with its core character. It has the potential and operative executive function, without which there is neither mobility nor teleological process. Therefore, the soul and body are neither contrasting nor dualistic substances. They are the aspects of one indivisible life. He wrote that the soul governs the body and when the soul is inactive, the body governs the soul. Aristotle ascribed the soul's central location to 
Examples of spirituality defined according to current and philosopbical contexts

Table 1

\begin{tabular}{|c|c|}
\hline Definition of spirituality & Reference \\
\hline $\begin{array}{l}\text { "a search for the sacred" } \\
\text { "The aspect of humanity that refers to the way individuals } \\
\text { seek and express meaning and purpose; experience of } \\
\text { connectedness to the moment, to self, to others, to nature } \\
\text { and to the significant or sacred." }\end{array}$ & $\begin{array}{l}\text { Pargament (1999, } \\
\text { p.12) } \\
\text { Puchalski et al. (2009, } \\
\text { p. 887) }\end{array}$ \\
\hline $\begin{array}{l}\text { "Distinct from all other things - namely humanism, values, } \\
\text { morals and mental health - by its connection to that which } \\
\text { is sacred, the transcendent - that which is outside of the } \\
\text { self, and yet also within the self - in the Western traditions } \\
\text { is called God, Allah, HaShem, or a Higher Power; in } \\
\text { Eastern traditions may be called Brahman, manifestations } \\
\text { of Brahman, Buddha, Dao, or ultimate truth/reality." }\end{array}$ & Koenig $(2012$, p.3) \\
\hline $\begin{array}{l}\text { "a state of being attuned with God or the Divine } \\
\text { Intelligence that governs or harmonizes the universe" }\end{array}$ & $\begin{array}{l}\text { Scott \& Bergin }(2005, \\
\text { p.22) }\end{array}$ \\
\hline $\begin{array}{l}\text { "Personal and private as well as public and organized } \\
\text { manifestations of a relationship to the transcendent" }\end{array}$ & $\begin{array}{l}\text { Fitzpatrick (2013, p. } \\
\text { 318) }\end{array}$ \\
\hline $\begin{array}{l}\text { "The essence of Spirit is Freedom... the essence of matter } \\
\text { is Gravity. Matter is outside itself, whereas Spirit has its } \\
\text { centre in itself" (p.20). Spirit is self-contained existence. } \\
\text { Spirit is "the one immutably homogenous infinite - pure } \\
\text { Identity - which in its second phase separates from } \\
\text { itself..." }\end{array}$ & $\begin{array}{l}\text { Hegel (2009, pp. } 6024 \\
\& \text { 8668) }\end{array}$ \\
\hline $\begin{array}{l}\text { The non-physical part of a person which is the seat of } \\
\text { emotions and character; this regarded as surviving after } \\
\text { the death of the body, often as a ghost; supernatural } \\
\text { being; the prevailing or typical quality of mood... a } \\
\text { person's mood; courage, energy and determination; the } \\
\text { real meaning of something as opposed to its strict verbal } \\
\text { interpretation." }\end{array}$ & $\begin{array}{l}\text { Soanes \& Stevenson } \\
(2009, \text { p. 1391) }\end{array}$ \\
\hline
\end{tabular}

the heart, on the basis that diseases of the heart cause death, while psychological experiences, such as extreme joy or sorrow, may cause heart disease. He also stated that the heart is man's first embryonic and functional organ (Aristotle, 1986).

In recent times, it has been noticed that the dynamics of the human being is a spiritual entity thus attracting the attention of many if not all researchers of the essence of the human being (Koenig, 2015). Thus a review of the literature will examine how spirituality is defined and conceptualized according to philosophical and current contexts. Spirituality will be shown to be universal and different to religiosity, which is doctrinal and specific to certain cultures and groups.

\section{Definition of spirituality}

There are a wide variety of definitions of spirituality in the literature. A reason for this could be due to the fact that an exploration of the concept of spirituality involves the process of understanding how people fulfil what they consider to be the purpose of their lives (D'Sousa \& George, 2006). Additionally there does not appear to be any general agreement as to what constitutes the nature of spirituality. Some studies suggest that spirituality should be viewed within a multidimensional framework due to the wide variety of definitions and conceptualisations available (Hill et al., 2000; Spilka, 1993). Table 1 demonstrates how the term 'spirituality' can be defined according to current and philosophical contexts (table 1). 


\section{Universality of spirituality}

Early and more current literature suggests that the universal nature of spirituality cannot be denied. This is revealed in the inner voice that accompanies human beings, occurs from the moment a person becomes self-aware and continues until their last breath. Such a voice is universal and emanates from the very creation of the human being (Skovoroda, 1972; 1995).

Many great thinkers have embraced the universality of spirituality. For example, Paul Tillich (1886-1965) refers to absolute faith by means of which human beings discover absolute values within themselves, given by the Creator as the Holy Spirit (Tillich, 1952). These values are spiritual, always present, universal, stable, inaccessible to evaluation, analysis and reification, and within the richness of every human individual (Tillich, 1962). These absolute values are central to healthy human behaviour (Hlywa, 2006).

The deeper our understanding of the spiritual nature of the human being, the more we must accept that "local culture-specific expressions of it only resonate with us because they point to universal truths and common human experiences that connect us to deeper questions about the meaning of life itself..." (Mackay, 2009, p.6). Porter (2012) shows how "spiritual moments (in therapy) include a sense of universality, or connectedness, or a deep sense of belonging in the moment" (p.17). Reference is made to Waldergrave (2000) who holds a view of "spirituality that is essentially about relationships in all cultures" (p.66) and "...a universal spirituality that acknowledges the sacredness of people's stories, particularly in their exposure of pain" (p.155).

There is an increased awareness of spiritual issues, faith and religion both in the popular and scientific literature. There is also a divide in the beliefs and values in relation to spirituality and religion as highlighted by the many viewpoints, which have led to negative associations, especially concerning religion. Scott \& Bergin (2005) highlight this resurgence and especially, more recently in the light of global events involving religious matters such as the wars between Muslims, Christians and Jews and the sexual abuse of children by clergy.

The universal nature of spirituality and its connection to 'religiosity' will be reviewed below. It will be shown that religiosity and spirituality could be seen to be fundamentally different; the former being specific to certain cultures and groups whereas the latter being universal. In addition, it will be highlighted that religiosity, at times, can be viewed as an expression of spirituality (Pargament, 1999; Scott \& Bergin, 2005).

\section{Spirituality and religiosity}

The concepts of spirituality and religiosity have been considered for millennia and have been used both positively and negatively. Spiritual, according to Hegel (1770-1831) and many other philosophers, is viewed as freedom, and is therefore uncontrollable by any human being (Hegel, 2009). Persecution, human suffering, acts of violence; terrorism and wars are waged in the name of religion and thus for many laypersons and scientists, spirituality is seen as good and religion as bad (Scott \& Bergin, 2005).

Many people consider spirituality to be synonymous with religiosity and the words spirituality and religion are often used interchangeably (Koenig, 2012, p. 3). Some consider the two concepts as mutually exclusive, whereas others have shown that although these two concepts do not necessarily mean the same thing, they can overlap and have shared meaning and characteristics (Scott \& Bergin, 2005). Best and colleagues (2015, p. 3) have proposed that spirituality should not be confused with religion, which is the way some people experience spirituality, and thus a subset of human spirituality as a whole.

Many have suggested that spirituality emanates from within the person and is known by members of the Christian faith as the Holy Spirit (Hlywa, 2013; Kierkegaard, 1972; 1974; Miller \& Thoresen, 2003; Shubin, 2012; St. Thomas Aquinas, 1967; van Kaam, 1975). Thus, they have suggested that spirituality is innate and an authentic component of the human being. Spirituality can reveal itself in a person's dedication to a style of life and personal goal (van Kaam, 1966) and is viewed by many as a God-given inner voice, voice of one's heart, or the voice of one's conscience (Harman, 1981; Hlywa, 2013; Hlywa \& Dolan, 2014, 2016; Skovoroda, 1995).

In contrast, religion has been defined as a particular system of faith and worship (D'Souza \& George, 2006). Religions are created by groups of humans, are doctrinal in their nature and external to the individual, although religions could be based on spiritual entities (Viftrup et al., 2013). Thus, in the context of the individual, some have argued that spirituality and religion 
relate to some internal or external need, respectively (Koenig, McCullough, \& Larson, 2001).

Many agree that religion is a doctrine elaborated, formulated and accepted by a group of people or individuals (Koenig, 2012; Koenig, 2015). However, Scott \& Bergin (2005) support those who argue that polarizing religion as an institutional activity and spirituality as a private or individual expression is an oversimplification. They agree that religious beliefs and behaviors can be very personal, private, and sacred (Pargament, 1999).

Skovoroda opposed religious dogma including bishops and priests and he emphasized the equality of all humans as being God-like and having equal access, help and counselling to the Creator. He was accused of being anti-clerical. He vehemently denied this and said he was not criticising any church, pope, bishop or Patriarch. He simply indicated that God has created every human being with the Holy Spirit and this makes all humans equal, and responsible to God. Like Socrates, centuries before, he tested his hypothesis throughout his life. He believed that hypotheses and theories are only relevant if they are proven by experience (Shubin, 2012).

\section{History of involving spirituality in patient care}

The role of spirituality in psychotherapy research and practice has grown increasingly in the last few decades (Daniels \& Fitzpatrick, 2013). A review of the literature emphasises the importance of integrating spirituality as a key component in healthcare (Brümault-Phillips, et al., 2015). However, there does not appear to be any general agreement on the essence of spirituality and its involvement in the psychotherapeutic process (Ross, Kennedy, \& Macnab, 2015). Furthermore, findings suggest that the way in which spirituality is integrated into psychotherapy is not fully conceptualised or understood (Viftrup, Hvidt, \& Buus, 2013).

There is global agreement that spirituality is important for patient wellbeing in a wide variety of settings and spirituality needs should be incorporated into healthcare, however the role of the physician in discussing spirituality with the patient is unclear (Best, Butow, \& Olver, 2016). With respect to the researchers' important contributions in the incorporation of spirituality into the psychotherapeutic context (BrŭmaultPhillips et al., 2015; Koenig, 2015; Pargament, 2013) it is evident that the use of questions such as asking the patient "whether they are a spiritual person" (Salander, 2006) or how they incorporate spirituality into their lives (Cole \& Pargament, 1999; Fitchett, Emanuel, Handzo, Boyken, \& Wilkie, 2015) or how they find meaning in their lives (Breitbart, 2001; Childs, 2014; Frey, Daaleman, \& Peyton, 2005) and taking a spiritual history (Puchalski \& Romer, 2000) may be useful for research in a laboratory setting in order to inform practice. However, this has also shown to be contraindicated for the patient in a real therapeutic encounter (Best et al., 2015) as it can act as a suggestion (Hlywa \& Dolan, 2010-11).

\section{The role of the unconscious, spirituality and the inner voice}

Studies show that unconscious processes have a powerful influence on human functioning, contributing to both health and illness (Hlywa \& Dolan, 2016). The importance of the unconscious mind has been emphasised since ancient times. For example, as mentioned previously, Plato (427-347 BC) observed that the unconscious is part of the psyche of the human being. He described the unconscious mind as a wild beast within the human being, which cannot be eliminated but tamed to a certain degree (Plato, 1955).

Skovoroda (1972) referred to the unconscious as the "supraconscious" or the Holy Spirit that shines and shows a person the right way of life (Hlywa \& Dolan, 2016, p.25). Moreover, later theorists such as William James (1842-1910), a highly respected philosopher, psychologist and physician, referred to the unconscious as the "extra-marginal" and the greatest discovery in the human being (James, 2011).

Sigmund Freud (1856-1939), an Austrian neurologist and founder of psychoanalysis, attributed a negative role to the unconscious, highlighting that conscious activities of the human being are minimal. Freud likened the conscious to the tip of an iceberg that is immersed below the surface of the water (Freud, 1943). In his essay titled "The Ego and the Id" published in 1923, Freud wrote about the unconscious as representing repressed thoughts, usually of a sexual nature, which played an important role in determining human behaviour (Freud, 1988).

It has been suggested that hypnosis can be used to access the unconscious mind of the human being (Spiegel \& Spiegel, 2004; Wolberg, $1948 ; 1964)$. Moreover, others even go so far as to claim that the unconscious cannot be accessed 
in the absence of hypnosis (Forel, 1919; Wetterstrand, 1897; 1970). Thus, hypnosis will be considered in order to appreciate the essence of the human being and their spirituality.

\section{Hypnosis and hypnotic rest in allied health and medicine}

Challenges to hypnosis and its link to spirituality

There are many challenges facing the field of hypnosis due to the fact that hypnosis is not widely understood by some people and, for some, there are certain reactions and misconceptions to hypnosis. This is due to the sensationalism and lack of understanding that has been associated with hypnosis as a mysterious or altered state and one that causes people to lose control or remain open to suggestions by external forces (Meyerson, 2014). Pintar (2010) noted that the popular imagination about hypnosis has remained largely unchanged. This is partly due to the large number of different approaches and definitions of hypnosis in the literature and the lack of understanding as to the true nature of hypnosis as a naturally occurring phenomenon (Hlywa \& Dolan, 2010-2011).

In addition, there are many hypnosis researchers who, in attempting to dismiss what they perceive to be the mythical and sensationalistic ideas related to hypnosis, have emphasized the scientific applications of hypnosis within the parameters of defining science as a process where phenomena are physically observable and measurable (Theiler \& Evans, 2016). Many of these researchers have likened mythical interpretations of hypnosis to definitions of spirituality that imply power or control by an external force, mystical or religious dogma (Gezundhajt, 2007). For example, in recommending that clinical hypnosis be disconnected "from historical baggage tying [it] to spirituality and exorcism", Meyerson (2014) associates spirituality with mystical powers.

If one understands spirituality more broadly and accepts a both/and nonlinear approach to understanding science (Meyerson, p. 383), then spirituality can be understood as the internal invisible force within the human being that promotes the person's life (Hlywa \& Dolan, 2016). As such, spirituality has been defined as the innate capacity of every human being (van Kaam, 1975), a universal and authentic phenomenon (Skovoroda, 1995) and should be treated very seriously in the therapeutic encounter (Hlywa \& Dolan, 2010-2011; Jung, 2001; Seaward, 2000).
Clinical utility/effectiveness and efficacy of hypnosis and hypnotic rest

Today, hypnosis is used extensively as a form of treatment as well as a research tool (Jamieson, 2007; Radovanиеvіж, 2009). The recent literature highlights the large number of practitioners and researchers that are using hypnosis in both allied health and medicine (Flammer \& Alladin, 2007; Jensen et al. 2015; Weisberg, 2008).

Studies confirm the effectiveness of hypnotherapy in the treatment of chronic pain and anxiety (Davis, 2016). There is also growing evidence to support the use of hypnosis interventions for pain and suffering management in severe chronic diseases and palliative care (Brugnoli, 2016).

There is a large body of research that validates the efficacy of hypnosis as part of the integrative treatment of many conditions that traditional medicine has found difficult to treat (Hartmann \& Zimberoff, 2011). There is also evidence that in these populations hypnosis can lead not only to reduced anxiety but also specifically altered physiological parameters (Hartmann \& Zimberoff, 2011). Meta-analyses points to the efficacy of medical hypnosis as a safe and effective complementary technique in somatic medicine, and that waking suggestions can be a component of effective doctor-patient communication in routine clinical situations (Häuser, Hagl, Schmierer, \& Hansen, 2016).

There are far fewer current studies reported on the efficacy and effectiveness (clinical utility) of hypnotic rest despite the fact that many of the current researchers allude to the concept of hypnotic rest/sleep in their methods and discussion of results. This is evident in the many references to rest and sleep in the use of hypnotic scripts and verbal suggestions in the methodology and protocols of the research studies. For example, Brugnoli (2016), refers to the phenomenon of "sleep" in her discussion on using selfhypnosis for acute pain management in part of her verbal script for suggestive sleep: "Now I will sleep...meanwhile my pain will decrease" (p.285).

However, there are several less recent studies that report positive results and these will be discussed under hypnotic rest below.

In order to understand the process of hypnotic rest it is necessary to understand the phenomenon of hypnosis and how it is conceptualised and defined in the literature. This will be followed by a review of the applications of hypnotic rest in the literature. 


\section{Review of the history of hypnosis}

Hypnosis can be considered to be one of the oldest curative methods (Brown \& Fromm, 1986; Meares, 1972). The earliest recorded roots of hypnotic practices in healing have been traced way back to ancient Hindu and Egyptian practices as well as the earliest sleep temples in Greece and Rome that were dedicated to the physician-God Asclepiades, who treated pain by stroking with his hands and inducing prolonged states of sleep (Hammond, 2013).

Modern hypnosis started with the Austrian physician Franz Anton Mesmer (1734-1815), who believed that the phenomenon known as mesmerism, or animal magnetism, or fluidum was related to an invisible substance - a fluid that runs within the subject or between the subject and the therapist, that is, the hypnotist, or the "magnetizer" (Mesmer, 1980). It is generally believed, according to the literature, that James Braid (1795-1860), a Scottish surgeon, created the term hypnosis from the Greek word 'hypnos', meaning 'to sleep' as a particular state of sleep - a trance (Braid, 1843).

In the late 19th century, a French neurologist Jean Martin Charcot (1825-1893) thought hypnotism to be a special physiological state, and his contemporary Hyppotite-Marie Bernheim (1840-1919) believed it to be a psychological state of heightened suggestibility. Sigmund Freud (1943), who studied with Charcot, used hypnosis early in his career to help patients recover repressed memories. He noted that patients would relive traumatic events while under hypnosis, a process known as abreaction (Hlywa, 2008; Wolberg, 1967). Freud later replaced hypnosis with the technique of free associations.

\section{Review of the definitions of hypnosis - research laboratories and real-life practice}

There are many definitions and applications of hypnosis and to date there is not one specific theory or approach researched in evidenced based laboratories that has been accepted as the most effective (Elkins, Barabasz, Council \& Spiegel, 2015; Lyn et al., 2015). Nor is there general consensus on the definition and core fundamentals of the process of hypnosis and this is evident in the changes to the APA definition of hypnosis over time (American Psychological Association, 2005; 2017).

Milton Erickson (1980), who is considered to be the father of modern hypnotherapy, differentiated between hypnosis in the context of scientific research laboratories and hypnosis in real-life practice. He noted that the lack of general consensus on what hypnosis is relates to the large amount of research in laboratory settings, which has objectified the process of hypnosis and created many different views and definitions of hypnosis. He emphasised that hypnosis is "a special state that intensifies the therapeutic relationship and focuses the patient's attention on a few inner realities [and] does not insure the acceptance of suggestions" (Erickson, et al., 1976, p. 19).

\section{Hypnosis defined as inherent, enhanced potentiality}

Contrary to the popular belief that hypnosis is primarily suggestion, hypnosis can also occur by "utilizing" (Erickson, 1967; Erickson, Rossi \& Rossi, 1976) the person's natural and "spontaneous enhanced potentiality" (Hlywa \& Dolan, 2010). Depending on the individual's hypnotic potential, hypnosis can occur spontaneously without the assistance of the therapist. Examples of spontaneous hypnosis include when an individual is in an absolute and highly profound state of focus or absorbed state such as a light daydream (Spiegel \& Greenleaf, 2005; Spiegel \& Spiegel, 1978; 2004).

Hlywa \& Dolan (2010-2011) introduced a new definition of hypnosis as the:

inherent, enhanced potentiality of human beings, which spontaneously appears in human life and which is also tapped by certain procedures known as hypnotic induction (p.125).

Such a definition of the phenomenon of hypnosis became apparent to the authors as more accurately descriptive of naturally occurring hypnosis, as a result of decade's long observation and utilization in psychotherapeutic practice. When the person is in a hypnotic state, whether it is formal or informal, their perceptions are heightened. In this heightened state, potentiality is enhanced, which can be negative (e.g. panic attack due to heightened fear) or positive (e.g. tapping into their inherent potential). In the positive state, healing is promoted due to enhanced potentiality (Hlywa \& Dolan, 2010).

Defining hypnosis as "inherent, enhanced potentiality" (Hlywa \& Dolan, 2010-2011, p.91) embraces the spontaneity and naturalness of the experience of hypnosis and emphasizes the Creator's gift that the person is born with unique potential and opportunity to be in control of themselves and make decisions for themselves every moment of their lives (Hlywa, 2013; Skovoroda, 1995). 
In a previous paper, Hlywa \& Dolan, 2010 expressed their concerns that the official APA definition of "hypnosis" (Division 30, American Psychological Association, 2005) excluded the spiritual dimension, and showed how hypnosis could not be defined in the absence of spirituality, which they made explicit in their definition of hypnosis as the enhanced potentiality or life force inherent within the human being which appears spontaneously at birth (Hlywa \& Dolan, 2010). They challenged the view that "hypnosis," as defined by the APA Division 30(2005), would:

ever suffice to explain the essence of the phenomenon referred to as hypnosis... because, by virtue of experimental constrictions / conditions (including pre-and hypnotic induction, where the experimenters "explain", "suggest using imagination," implicitly or verbally), the phenomenon is contaminated by the subject's capacity for enhanced suggestion... thus the phenomenon under investigation is not the pristine phenomenon as it naturally occurs. It is an artifact created by the subject with the experimenter, by means of which a certain capacity - but not the essence of the phenomenon - is being investigated (Hlywa \& Dolan, 2010, p. 41).

In view of the above, it is interesting to note that the APA Division 30 (2014) have since revised their definition of hypnosis to apparently reflect a more "atheoretical definition" which they propose in view of the many different approaches and definitions of hypnosis in the literature to date. They define hypnosis as "a state of consciousness involving focused attention and reduced peripheral awareness characterized by an enhanced capacity for response to suggestion".

In considering all human behaviour, it has been shown that, with the aid of the understanding of human potentiality in the hypnotic state, we can understand much more deeply the educational potentiality, achievements, endurance, will and many other human phenomena (Hlywa, 1998; 2008a; 2009). This is in addition to considering the application of hypnosis in treating psychopathological states. In other words, hypnosis helps us to understand many phenomena in human life, in its healthy and pathological state (Spiegel \& Spiegel, 1978; 2004).

Researchers have proposed that hypnosis, especially in children until the age of about 1214 years, is a daily occurrence, which plays a tremendous role in structuring the foundation of the personality of the human being (London, 1962; Morgan \& Hilgard, 1973). The person in hypnosis adopts, uncritically, any suggestions emanating from some unknown internal or external forces. The unconscious elements in human behaviour that are acquired from unknown stimuli could be discovered more easily in the hypnotherapeutic process because it has been show that the royal road to the unconscious is through hypnotic trance (Spiegel \& Spiegel, 1978; 2004). This facilitates the revision of the individual towards themselves and their environment.

\section{Hypnosis and the therapeutic relationship}

Studies have shown that hypnosis is a powerful ingredient in rapidly creating the perfect psychotherapeutic relationship (Brown \& Fromm, 1986; Hlywa, 2009; Spiegel \& Greenleaf, 2005; Wolberg, 1964). It has been acknowledged that a positive psychotherapeutic relationship, which is usually achieved during quite a few sessions on the conscious level, is achieved within a very short space of time in the hypnotic relationship (Hlywa, 2009; Meares, 1967).

Herbert Spiegel (1914-2009) developed a clinical tool, the Hypnotic Induction Profile (HIP), to assess the patient's capacity for the hypnotic intervention due to its short and reliable qualities (Spiegel \& Spiegel, 1978; 2004). The HIP can be utilised to precipitate the therapeutic process (Hlywa, 2008b). In this profile the patient's hypnotic capacity is measured in order to determine their capacity to benefit from the hypnotherapy. A clinician who is experienced in utilising this clinical tool is able to incorporate it naturally and spontaneously as part of the therapeutic process (Hlywa, 2008b; Spiegel, 2004).

\section{Hypnotic rest}

The restorative process of rest has been the standard medical advice to patients since antiquity, and yet, natural sleep and rest are elusive for some people and medications are often prescribed (Hlywa, 2008a). Around 5000BC, the Egyptians used "sacred sleep" for therapeutic purposes. Around 500BC in Greece, the Asklepios temples of sleep were used for healing (Kleinhauz, 1991). These temples were sacred to the Greek god physician and surgeon, Asklepios (Askitopoulou, Konsolaki, Ramoutsaki \& Anastassaki, 2002). 
The first recorded use of deep sleep for anaesthesia in the Holy Bible is found in the very first book of Genesis (International Bible Society, 1978) where it is written that:

God caused the man to fall into a deep sleep; and while he was sleeping, he took one of the man's ribs and closed up the place with flesh (Genesis chapter 2 verse 21, p. 3).

\section{Earliest reported studies on hypnotic rest Prolonged hypnosis}

The early scientific literature on the clinical application of prolonged hypnosis is evidenced in the work of the Swedish psychiatrist Otto Georg Wetterstrand $(1897 ; 1970)$. In his clinical case studies he reported improvements in several hundreds of cases by inducing patients into a deep trance, with or without medication, and keeping them in trance for many hours and sometimes days. He reported favorable results in the treatment of several physical and mental health conditions, including insomnia, headaches, neuralgia, epilepsy, chronic vomiting, neurasthenia, chorea, stomach diseases, skin conditions, asthma, obstetrics and hysteria.

\section{Hypnotic drugs used for prolonged rest}

Historical studies also report favorable results in the use of hypnotic drugs to induce prolonged rest. In the 1920's prolonged sleep induced by sleep-inducing drugs called soporific pharmaceuticals (e.g. Somnifen; Cloettal) were used as therapy for schizophrenia with positive results in 25 to 33 percent of all cases (Windholz \& Witherspoon, 1993). The therapy was indicated for what was described as psychogenic schizophrenias and contraindicated for organic conditions including paranoid schizophrenia and hebephrenia. Although some researchers reported remission in symptoms especially if the therapy was followed by psychotherapy, by the mid 1930's the use of drug-induced prolonged sleep therapy declined due to the reported dangerous side effects of the drugs, including death, in some cases.

\section{Platonov's use of the word as a therapeutic factor in prolonged suggestive rest}

Platonov (1959) recorded numerous and convincing amounts of experimental research and clinical studies confirming the effectiveness of prolonged hypnotic rest. In his experimental laboratories in Ukraine, he reported favorable results using "long-continued suggestive sleep as an auxiliary therapeutic method" (p. 234235). The complete rest was usually induced by special suggestion, used in more or less distressing conditions as a concluding method after each session of psychotherapy and served to enhance and consolidate the therapeutic effect obtained. It also served to restore the functions of the cortical cells. Treatment was administered at repeated sessions, several hours per day, on subsequent days, and complemented with therapeutic verbal suggestions.

Platonov (1959) differentiated between the active state of "complete rest" from the typical state of suggested sleep and drug-induced sleep. He noted that the former "involves a maximal activation of the restorative function of the cerebral cortex" (p.235). He emphasized the importance of the Russian Pavlovian School who were instrumental in researching the physiological mechanisms underlying this state of sleep. He mentioned the experimental research by Pavlov's associate, Petrov, who, in 1945, proved the superiority of suggested sleep over pharmacological sleep in treating eczema and ulcers in neurotic dogs.

Platonov (1959) confirmed Pavlov's significant experimental findings in his own observations and those of his Ukrainian colleagues. He also recorded examples of the use of protracted suggestive sleep in the work of several researchers in Ukraine laboratories, including:

- Prusenko's group method of using "protracted suggested sleep" to treat adolescent patients suffering from "increased excitability of the nervous system"

- Kashpur obtained positive results from prolonged suggested sleep in the treatment of neurotics

- Strelchuk treated dipsomaniacs using long suggested sleep

- Kopil-Levina and Tsvetkov found that long suggested sleep restored the strength of a woman in childbirth during protracted parturition and there was no need for the use of forceps

- Schilder and Kauder (in 1926) and Rottenberg (in 1928) had both applied protracted hypnotic rest in various psychosomatic conditions.

Platonov (1959, pp. 234-238) confirmed the therapeutic value of suggested rest and concluded that "long suggested sleep" is especially indicated in cases where exhausting factors affected the nervous system for a long time. For example after most distressing experiences, serious surgical operations, difficult protracted 
parturition, grave somatic ailments, general fatigue and high nervous excitability. He recommended the use of protracted suggested sleep during the pre and post-operative periods. $\mathrm{He}$ also recommended the use of such rest in the prophylactics of hypertension, in treating ulcers, in the early stages of tuberculosis and generally in all cases where it is necessary to rapidly restore a patient's health. He added that protracted suggested sleep is one of the most important therapeutic methods used with neurotic ailments, once the basic pathogenic factors have been treated and removed by verbal suggestion.

In considering Platonov's significant contribution to research in prolonged hypnotic rest, it is important to understand the context of where he and his colleagues were working and what the State demanded at that time by physicians and psychologists. This meant that spirituality was excluded and Platonov (1959) acknowledged this in his writings. According to this physiological model, all human beings were products of genes and must be considered that way. Human beings were considered to be on the highest level of physiological development and such entities that did not have a biological basis (e.g. psyche, spirit, soul) did not exist.

In this Pavlovian era in the Soviet Union, researchers in hypnosis were acting according to the approved medical model where, according to the patient history, diagnosis was made and the patient was treated according to the medical model. Thus, Platonov (1959) emphasized that, before protracted hypnotic rest could be utilized on the patient, a detailed medical history must be taken, appropriate psychotherapy instituted on conscious and hypnotic levels, and then, if indicated, consolidation obtained with the assistance of protracted hypnotic rest. Even though that was in the 1950's in the Soviet Union, it is evident that this attitude of excluding any spiritual (nonphysical) reference is no different today in the medical model where everything must be based on what is seen, that is, on material reality, that could be observed, weighed and measured (Paxinos, 2016).

\section{More recent studies on hypnotic rest}

A review of current literature suggests that hypnotic rest has not been widely recognised in evidence-based practice. However there are a few studies published, which have utilised hypnotic rest as an effective treatment. These are outlined below.

\section{Prolonged hypnotic rest}

Hlywa (2009) detailed an outline of a successfully conducted group experience of "Prolonged Hypnotic Rest". He advised that the method of protracted hypnotic rest be utilised by experienced practitioners in psychotherapy and hypnotherapy, under the guidance of medical practitioners, as close medical monitoring is necessary in such procedures. This was necessary in a group situation where there may be a spontaneous abreaction, which could require individual attention. However, in an individual utilisation of such an approach, a skilled hypnotherapist can eliminate and/or appropriately manage the possibility of spontaneous abreaction by facilitating the person in a way that they are working towards establishing and implementing their own goal (Hlywa, 2008b).

The Japanese physician, Kazuya Kuriyama (1968) applied his method of prolonged hypnosis to various types of psychosomatic conditions. He reported his results on 27 patients and detailed 3 case studies. He described his extensive clinical and experimental procedure and found that prolonged hypnosis promotes the inherent self-recovering force and enhances the effect of the trance to an optimal level. He found that prolonged hypnosis protects the patient from external stimuli and disturbances and eliminates the tension state created by wrong learning. He noted further that the "feeling of security and satisfaction that come from the fact that the patient is treated well and long enough, add to more favorable results" (p. 102).

Kleinhauz (1991) demonstrated an individualized approach to using prolonged hypnosis in six patients and detailed favourable results in case reports. The treatment was based on achieving a prolonged hypnotic response, during which initial hypno-relaxation was used, together with an individualized plan that included self-hypnosis, suggestive procedures, use of metaphors and constructive imagery techniques. All six patients were treated in hospital and presented with diverse medical and psychological conditions including intractable pain.

\section{Prolonged hypnosis and sleep Drug-induced deep sleep therapy - The Nightmare at Chelmsford}

In the 1970's drug-induced deep sleep therapy was the subject of a Royal Commission of Enquiry at Chelmsford Private Hospital near Sydney (Pols, 2013). At least 24 patients died 
and many others were injured, severely traumatized and in some cases, there was brain damage and suicide. This experimental treatment method described as continuous narcosis or prolonged sleep therapy was administered to over 1000 patients with diagnoses varying from depression and anxiety to schizophrenia and neurosis. The treatment was conducted over a period of 15 years (1963-1979) by a psychiatrist, Harry Bailey and his colleagues. Patients were placed in a drug-induced deep sleep for up to two weeks while electro-shock therapy was administered at regular intervals. Various complications, including pneumonia, dehydration, bedsores and vomiting, were also reported.

Kratochvíl (1970a; 1970b; Kratochvíl \& Macdonald, 2011) researched prolonged hypnosis in the waking state and compared it to sleep. He kept his subjects in hypnotic rest for up to a fortnight. He suggested that people in hypnosis could continue their daily work and chores and maintain their regular routine. They were instructed to maintain diaries on a daily basis so he could determine from the diaries of his patients that they were continuing with their regular activities. There were no external signs they were in trance, and the only indication he had that they were in hypnotic rest is that they would recognise one date and record this in their diary. Thus they were in the trance, maintaining regular habits, including working, sleeping, eating and social relations.

\section{Prolonged hypnotic sleep}

Meares (1972) reported his use of "prolonged hypnotic sleep" with chronically disturbed, restless, agitated and anxious psychoneurotics (p.274). The late Dr. Ainslie Meares, an Australian psychiatrist and Professor of Psychiatry at the University of Melbourne, is recognised as a world pioneer of hypnosis and published his book on the medical use of hypnosis, detailing his atavistic theory of hypnosis. He worked for thirty years as a psychiatrist and published hundreds of scientific papers in peer-reviewed journals. He used hypnosis and later, what he described as 'stillness meditation', extensively in the treatment of psychoneurotic, psychosomatic illnesses, cancer and stress. Although he reported positive results with hypnosis, he found that patients did not resolve deeper conflicts with symptom removal. He eventually moved away from practising formal medical hypnosis due to the success he experienced with the nonverbal and less suggestive approaches to helping his patients with prolonged hypnotic rest. Thus he moved away from psychiatry and towards what he experienced to be the more curative aspects of healing.

Meares (1976) reported positive results for the regression of cancer in "intensive meditation" by what he described as "extreme simplicity and stillness of the mind" where he proposed that patients rest in stillness and will find their inner calm (Meares, 1982-1983, p.114). He first described his work as "mental relaxation" and then coined the phrase "mental ataraxis" meaning absence of disturbance of the mind (Meares, 1979). It cannot be denied that his depth of understanding in the principles and clinical applications of hypnosis were inherent in his unique approach to meditation. Later he adopted the terminology 'meditative relaxation', and as the idea of meditation generally grew in popularity within Western culture, the broader term 'meditation' was employed. His contribution to the field of meditation is described below.

\section{Hypnosis and meditation}

Meares used his form of intensive meditation described as stillness meditation therapy and reported positive outcomes for relief of anxiety and pain, symptoms of stress and depression, leading to a more fulfilling and rewarding life (Zwar, 1985). He described his approach to meditation as an effortless experience where people return to a natural state of being without any trying or striving. While honoring the value of traditional meditation, from a medical perspective he developed a theory that differs significantly from meditation as it is generally used.

His objective related only to assisting people in accessing simply the natural undisturbed calm within them through the facilitated therapeutic experience of stillness. His method was to place the person into hypnotic rest, by suggesting that they become comfortable and go into rest. He then left them in hypnotic rest for several hours or even days and weeks. There are no external suggestions such as use of a mantra, use of music, chanting, nor is there visualization or breathing techniques and with such an approach the mind experiences rest, reaching a point of "atavistic regression", a more biologically primitive, mental state (Meares, 1972). This is significant as it leads to an absence of disturbance within the mind, a point where the mind does not register 
discomfort or emotion of any kind. In this state of profound rest, the minds own powers of healing can be activated (Meares, 1972). He reported evidence to show that this form of meditation is much more effective than other forms in restoring the harmonious brain function that relieves stress.

Meares (1979) differentiated his approach to the more traditional meditation techniques (e.g. classical meditation as in yoga, in Zen Buddhist meditation, and in the meditation as practiced by the early Christian mystics) where the thought processes of the mind are helped by will power concentrating on some object or spiritual concept. In these approaches as is evidenced in the more current approaches to mindfulness and meditation, the mind is active and striving to attain and maintain a focus, a mantra or an ideal. For example, the meditator is taught to be constantly aware of their breathing and thus this awareness or mindfulness suggests that there is continuing activity of the mind and as such, the brain never achieves the quiet stillness which is so effective in restoring harmonious function and relieving stress.

\section{Hypnosis and mindfulness meditation}

More recently mindfulness meditation has been integrated with hypnosis in various studies (Otani, 2016; Alladin, 2014; Yapko, 2001). These approaches appear to emphasize the hypnotic factors of absorption, focus, expectancy, and suggestion as fundamental in the integration of hypnosis with mindfulness meditation.

The evidenced based approach has emphasized meditative and mindfulness techniques that encourage adherence to a mantra or a visualization, which is often externally suggested (Melbourne Academic Mindfulness Interest Group, 2006). Thus it is seen as something practical, as a coping technique or a strategy that can be easily learned as opposed to the rather mystical idea of stillness.

\section{Contraindications for hypnosis}

There are strict and ethical guidelines in the use of hypnosis, which include indications and contraindications for its use (Australian Psychological Society, 2016). This includes proper training and experience in understanding psychopathology (Spiegel \& Spiegel, 2004). This also includes measuring the goals the patient wants to achieve or get rid of as an accepted code of behavior in the context of sociological, legal, health and economic factors (Hlywa, 1998; 2004; 2008).

It has been shown that hypnosis is contraindicated in certain conditions and should be excluded in psychosis, fear of hypnosis and other objections (e.g. personal, cultural, religious, psychological), that may prevent the person from fearlessly entering the hypnotic rest (Platonov, 1959; Spiegel \& Spiegel, 2004).

It is widely accepted according to standard ethical practice that the practice of hypnotherapy requires an understanding of human dynamics, health and illness (American Psychological Association, 2005; Australian Psychological Society, 2016). Thus, a comprehensive and thorough understanding of the principles of psychotherapy is essential to the sound practice of hypnotherapy and hypnotic rest.

\section{The Psychotherapeutic process}

The following review of the psychotherapeutic process will include a brief elaboration on the definition of psychotherapy. Reference to some of the more significant models of treatment will highlight how each theorist's particular approach to understanding the human being can influence the patient in the form of suggestions given to them by the therapist who is considered to be the expert in helping them find solutions to their problems. Yet, to date there is no one approach that has been considered to be more effective. A review of the common factors that are shown to be effective in achieving positive outcomes in therapy will highlight how an integrative approach to patient care embraces the importance of a consideration of the inner voice and its role in helping the person achieve health and happiness.

\section{Definition of psychotherapy}

A review of the literature highlights the large and growing number of psychotherapies. In the early 1980's at least 250 different psychotherapies were reported (Corsini \& Wedding, 1989; Herink, 1980). More recently Prochaska (2014) estimated there to be over 500 therapies and today the number is expected to be even higher. However, no single definition of psychotherapy has gained universal acceptance (Prochaska \& Norcross, 2014). The definition of psychotherapy used is largely dependent on the theoretical orientation, paradigm or worldview and the specific approach to psychotherapy.

Psychotherapy has been defined as a condition deliberately and skilfully created by a therapist, 
where the patient is able to revise their attitude to their environment and most importantly towards them self, because, it has been shown that loyalty to one's internal voice leads to health and happiness (Hlywa, 2009; 2013; Skovoroda, 1972).

Heidegger (1962) referred to the person's environment in terms of "Umwelt" (distant environment), "Mitwelt" (close environment e.g. society, family); and "Eigenwelt" (internal environment i.e. one's own). Ivey et al. (2012) noted how psychotherapy has been usually regarded as a highly verbal process. The authors showed how silence could be utilised as a way of respecting the individual (Eigenwelt), developing a trusting relationship (Mitwelt), and working within the client's culture (Umwelt) (p.392). This process is elaborated in the current study where it is proposed that reexamining one's attitude towards oneself can be seen as one of the most important factors in psychotherapy and is enhanced with a consideration of spirituality (Hlywa, 2008a; Vontress, 1995).

Such analysis of one's attitude to one's environment and oneself (a process on the conscious and altered conscious level) facilitates the patient to be able to make and be responsible for their decisions (Hlywa, 2009). This is reflected in the writings of the French philosopher JeanPaul Sartre, who expressed the generally approved view that the duty of every human being is to decide for oneself. Sartre emphasised that it is only the human being who has been endowed with intellect, free will and the capacity of knowing oneself, thus capable of making decisions for oneself and being responsible for the decisions made (Sartre, 1956).

\section{A brief overview of some significant psychotherapeutic treatment modalities}

There are a number of different ways to categorize psychological therapy. For example, Prochaska \& Norcross (2014) categorized the approaches as follows: cognitive and behaviour, psychoanalytic and psychodynamic, humanistic, existential, experiential, interpersonal, systemic, gender-sensitive, multicultural, constructivist, integrative and trans-theoretical. Corey's (2013) description of some common psychotherapeutic approaches is shown below in Table 2 .

Despite the diversity of psychotherapeutic models the evidence to date suggests that there is no single psychotherapeutic approach that is more effective than another (Prochaska \&
Norcross, 2014). Studies suggest that there are common ingredients pertaining to all psychotherapies regardless of their orientation (Ivey et al., 2012). These common ingredients have been shown to be associated with positive outcomes in psychotherapy and will be discussed below in relation to the role of the inner voice, spirituality and hypnotic rest as proposed in the current study.

\section{The psychotherapeutic relationship}

Psychotherapy outcome studies indicate that only a $1 \%$ variance in treatment outcomes can be attributed to different psychotherapeutic models (Wampold, 2001). This has left the critical question of what accounts for treatment effects unanswered (Pargament, Lomax, McGee, \& Fang, 2014).

The psychotherapeutic relationship has been shown to be accountable for the most significant part of the variance in treatment outcomes (Horvath, Del Re, Fluckiger, \& Symonds, 2011; Hubble, Duncan, Miller, \& Wampold, 2010). Carl Rogers (1902-1987), a highly respected psychologist and one of the key founders of humanistic psychology, claimed that the most important ingredient in the psychotherapeutic encounter is the relationship between the therapist and the patient (Rogers, 1942).

Rogers proposed a person-centred approach to psychotherapy (Rogers, 1986). From a personcentred perspective the duty of a psychotherapist is to be neutral but involved in the experience referred to as "we-ness" (Watkins \& Barabasz, 2008, p.91), when trying to understand and assist the person to revise his or her own attitude towards themself. Therefore, not by virtue of discussion or questioning but by a process of togetherness the patient and therapist become a single entity (Hlywa, 2009; Meares, 1967).

According to Rogers (1951) the only factor promoting life is within the human being. His treatment approach called 'client-centred therapy' has gained increased popularity in the last few years due to calls for a more person-centred approach to healthcare (National Mental Health Commission, 2014; Brŭmault-Phillips et al., 2015).

Rogers suggested that the prerogative of every human being is to evaluate, decide, and implement their free will into life. Therapeutic factors such as unconditional acceptance, positive regard, genuineness, warmth and empathy underlie Rogers' approach to treatment and emphasise the importance of the authentic and accepting nature of the therapist (Rogers, 1986). 
Models of Psychotherapy in the literature (Adapted from Corey, 2013)

\begin{tabular}{|c|c|}
\hline Definition of spirituality & Reference \\
\hline $\begin{array}{l}\text { "a search for the sacred" } \\
\text { "The aspect of humanity that refers to the way individuals } \\
\text { seek and express meaning and purpose; experience of } \\
\text { connectedness to the moment, to self, to others, to nature } \\
\text { and to the significant or sacred." }\end{array}$ & $\begin{array}{l}\text { Pargament (1999, } \\
\text { p.12) } \\
\text { Puchalski et al. (2009, } \\
\text { p. } 887)\end{array}$ \\
\hline $\begin{array}{l}\text { "Distinct from all other things - namely humanism, values, } \\
\text { morals and mental health - by its connection to that which } \\
\text { is sacred, the transcendent - that which is outside of the } \\
\text { self, and yet also within the self - in the Western traditions } \\
\text { is called God, Allah, HaShem, or a Higher Power; in } \\
\text { Eastern traditions may be called Brahman, manifestations } \\
\text { of Brahman, Buddha, Dao, or ultimate truth/reality." }\end{array}$ & Koenig $(2012$, p.3) \\
\hline $\begin{array}{l}\text { "a state of being attuned with God or the Divine } \\
\text { Intelligence that governs or harmonizes the universe" }\end{array}$ & $\begin{array}{l}\text { Scott \& Bergin }(2005 \\
\text { p.22) }\end{array}$ \\
\hline $\begin{array}{l}\text { "Personal and private as well as public and organized } \\
\text { manifestations of a relationship to the transcendent" }\end{array}$ & $\begin{array}{l}\text { Fitzpatrick (2013, p. } \\
\text { 318) }\end{array}$ \\
\hline $\begin{array}{l}\text { "The essence of Spirit is Freedom... the essence of matter } \\
\text { is Gravity. Matter is outside itself, whereas Spirit has its } \\
\text { centre in itself" (p.20). Spirit is self-contained existence. } \\
\text { Spirit is "the one immutably homogenous infinite - pure } \\
\text { Identity - which in its second phase separates from } \\
\text { itself..." }\end{array}$ & $\begin{array}{l}\text { Hegel (2009, pp. } 6024 \\
\& 8668)\end{array}$ \\
\hline $\begin{array}{l}\text { The non-physical part of a person which is the seat of } \\
\text { emotions and character; this regarded as surviving after } \\
\text { the death of the body, often as a ghost; supernatural } \\
\text { being; the prevailing or typical quality of mood... a } \\
\text { person's mood; courage, energy and determination; the } \\
\text { real meaning of something as opposed to its strict verbal } \\
\text { interpretation." }\end{array}$ & $\begin{array}{l}\text { Soanes \& Stevenson } \\
\text { (2009, p. 1391) }\end{array}$ \\
\hline
\end{tabular}

The literature on psychotherapy suggests that the therapeutic alliance and therapist attributes are important to treatment outcomes regardless of the therapist's theoretical orientation, perhaps more so than the factors specific to different therapies (Wampold, 2007). In some studies therapeutic alliances are associated with outcomes in psychotherapy over and above diagnosis and treatment modality (Duncan, et al., 2010). The therapist's skill in forming treatment alliances is strongly associated with positive treatment outcome - more so than are treatment variables (Wampold, 2007). This suggests that patients will be more likely to experience positive therapeutic outcomes when working with a therapist who is skilled in establishing and maintaining working alliances.

There is also evidence that therapist empathy is associated with positive outcomes in psychotherapy (Duncan, et al. 2010) regardless of therapist theoretical orientation (Elliott, Bohart, Watson \& Greenberg, 2011). Likewise, metaanalysis indicates that a therapist attitude of non-possessive warmth and acceptance is associated with therapeutic success (Farber \& Doolin, 2011). It seems possible, then, that warm, empathic therapists, regardless of the type of therapy they provide, are likely to provide the most effective treatment. 


\section{Adopting a holistic approach}

The literature highlights the move towards more holistic interventions that incorporate an integrative approach to treatment (Ivey et al., 2012). A holistic approach to treatment represents the move away from the linear and compartmentalised approach of viewing symptoms in material and cause-effect perspectives, towards the attempt to understand the person's expression of symptoms in a non-causal, non-material, yet influential and dynamic relationship (Dolan, 2000).

This is in line with the move away from the Newtonian paradigm of dualism, as expressed in the medical model, where mind and body were viewed as separate entities. This natural tendency to compartmentalise was used to facilitate an understanding of the presentation of symptoms and how to remove or cure the person of such symptoms. Moreover, it has been found that a holistic model of individual functioning treats the individual as a bio-psycho-socialspiritual entity, where spirituality is at the very core of the therapeutic process (Dolan, 2000, p.90).

\section{Spirituality, hypnotherapy and psychotherapy - Towards integration: Bringing everything together in the inner voice}

The term psychotherapy implies that we are dealing with the human psyche (Jung, 1960) and psyche in Greek is defined as "spirit or soul" (Soanes \& Stevenson, 2009). Therefore the spirit or the soul can be shown to have profound central importance and relevance in psychotherapy. The importance of spirituality in patient care has already been discussed however its relevance to the psychotherapeutic process will be expanded below.

\section{The essence of spirituality in the therapeutic process}

As noted earlier spirituality can be viewed as the internal essence of the human being (Jung, 2001; van Kaam, 1966), which suggests that spirituality may be a crucial factor in psychotherapy (Hlywa \& Dolan, 2010; 2011; 2016; Jung, 2001). Therefore, it is not surprising that some (e.g. Ivey et al., 2012) have recommended spirituality be integrated into the process of treatment. For example Gockel (2011) differentiated between implicit and explicit integration of spirituality into the therapy process. She claimed that the implicit integration of spirituality informs a therapist's views, practices, and interventions. In contrast, explicit integration overtly addresses spiritual issues by asking questions in the form of taking a client's spiritual history, discussing spirituality as part of the therapy process, or by using spiritual interventions such as prayer or meditation with the client.

Findings from empirical studies suggest that the spiritual character of the therapeutic relationship is not only a key ingredient of therapeutic change, but that these "sacred qualities" can be measured systematically (Pargament et al., 2014, p. 249). However, there does not appear to be any consensus on the essence of spirituality and its involvement in the psychotherapeutic process (Seaward, 2000; Viftrup et al., 2013). Thus, given this confusion, there may be a lack of consistency in the way the phenomenon of spirituality is being incorporated into the psychotherapeutic process. If this is the case, further investigation is required.

Hlywa (2009) described how the therapeutic process is a specially created psychotherapeutic relationship, which calls for the patient to reexamine one's attitude towards the universe and most importantly, the attitude towards oneself. This process empowers the patient to be truly human and make a decision and implement it in the real life. He proposed that any intervention, which is imposed onto the patient in this process of self re-examination, could only pollute the patient's way to get to know oneself (Hlywa, 1998; 2004; 2009).

He proposed further that the psychotherapist must be thoroughly acquainted with and respect the different religious and cultural backgrounds of one's patients, because spiritual essence contains the factor of faith and faith can help the person to obtain a positive result for their therapy (Hlywa, 2013). The innate capacity of human beings to adhere to and respect human values is referred to as the collective unconscious (Jung, 1960). Without the use of questioning, it will be shown that it is possible to become acquainted with the patient's essential background by a process that Watkins \& Barabasz (2008, p.91) refer to as 'we-ness'.

\section{Spirituality, the inner voice and symptom expression}

It has been shown how the power of the inner voice in symptom expression can have such a profound influence on the human psyche, leading to internal trauma or conflict, severe physiolo- 
gical and psychological distress (Hlywa \& Dolan, 2016). The signs and symptoms of physical and mental illnesses can be viewed as expressions of internal trauma, resulting in vilification of spirituality (Hlywa \& Dolan, 2016). Thus it may be part of the psychotherapy experience to process and gain insight into the spiritual nature and meaning of one's symptoms, and to find resolution and healing.

\section{A number of case studies have been published in this area}

For example:

1. A boy suffering from rheumatoid arthritis, undergoing treatment for severe pain, inflammation and deformity, became symptom free after revivification and abreaction process in which he revealed his severe guilt for "his involvement in the death of his younger brother" (Hlywa \& Dolan, 2010-11)

2. A patient with depressed mood and PTSD (Hlywa \& Dolan, 2010-11)

3. A patient who presented with anorexia nervosa and PTSD (Hlywa \& Dolan, 2010)

4. A patient who presented with hysterical blindness, where a mother "was afraid of facing the death of her son" (Hlywa, 2008).

\section{CONCLUSION}

A review of Hryhorri Skovoroda's (1972) theory on the inner voice and spirituality (1972) highlights his unique contribution to understanding the essence of the human being. He went further then many other philosophers and researchers and proposed that every human being is endowed equally with the Creator's gifts and the voice of the Holy Spirit.

It has been shown how the appropriate use of psychotherapeutic phenomena, including the psychotherapeutic relationship, an understanding of the essence of the human being, hypnotic phenomena and a person-centred approach, can create the conditions within which the patient is able to acquire important insights into their own self and listen to their inner voice.

The evidence suggests that the essence or spirit of the human being is a very important consideration in the psychotherapeutic process and that incorporating spirituality promotes health and happiness. Yet, there appears to be a lack of consistency in the way the phenomenon of spirituality is being incorporated into the therapeutic process. Existing models of treatment focus on a reification of the concept of spiritua- lity, as opposed to a seamless integration of the phenomenon into the therapeutic process.

There is even less attention given to the role of the inner voice in the therapeutic process. In addition there appears to be a gap in the understanding and application of hypnotherapeutic rest and how the therapist creates an environment where the patient is able to revise their attitude towards themself and their environment, make decisions for themselves and be responsible for the decisions being made.

A review of the literature highlights the many approaches that have been found to be effective to assist patients improve their symptoms and lead a healthy and happy life. Most of these approaches have been acknowledged and applied as valid methods for patient care. They emphasize making suggestions to the patient to remove symptoms. Such external suggestions are based on expert knowledge or theories for facilitating health and happiness. These approaches to treatment form the acceptable and evidencedbased practices utilised by registered health practitioners. Examples of such methods include hypnotic suggestions, focussed strategies and coping mechanisms, cognitive, behavioural, systemic, humanistic and existential approaches that emphasize understanding the inner dynamics of the personality to find out what the patient is; religious approaches to counselling that suggest a certain worldview or belief system and lifestyle to follow to become happy and healthy; mindfulness and meditation and many more approaches to therapy.

Many of these theorists may very well support the 'idea' of respecting the person's inner voice however there is not much direct reference to the concept of listening to the inner voice as a central focus in treatment. This is partly due to the move away from philosophy, theology and understanding the essence of the human being towards what can be observed, measured and manipulated. It is acknowledged that the empirical research has contributed immensely to evidenced-based literature and peer-reviewed approaches to patient care. It is also acknowledged that, for many scientists and researchers, excluding the spiritual is a practical decision rooted in the methodological and conceptual assumption that things that cannot be observed, measured or reliably described relate to a different realm than science.

Whilst these approaches are valid and contribute to our knowledge base, they have been formulated to comply with research according 
to the movement of 'scientific modernism', as is evident in the medical model. The pace of development in science and technology has been acknowledged in the biological and physical fields and has increased in the behavioural sciences. The literature recognises the enormous contributions to experimental science and in the area of hypnosis there is a large experimental base in the field, including in neuroscience and consciousness. So it is evident that attempts are being made to make visible, what is unseen and invisible. However this has created a conflict for clinicians who are working with applying this scientific approach to the clinical phenomena that we observe in practice (Scott \& Bergin, 2005). Furthermore, there is a move away from the Newtonian paradigm of dualism, as expressed in the medical model, where mind and body are viewed as separate entities, towards a more holistic, integrative and person-centred approach to patient care.

In summary, the role of the inner voice has not been directly acknowledged in the literature and there is a gap in this crucial area in patient care. This study explores Skovoroda's contribution to the role of the inner voice and its application in hypnotherapeutic rest.

\section{REFERENCES}

Adler, A. (1964). Social interest: a challenge to mankind. New York: Capricorn.

Adler, A. (1969). Understanding human nature. New York: Fawcett Crest.

Al Rubaie, T. (2002). The rehabilitation of the case-study method, European Journal of Psychotherapy \& Counselling, 5(1), 31-47, doi:10.1080/13642530210159198

American Psychological Association. (2005; 2014; 2017). Society of Psychological Hypnosis: Division 30-American Psychological Association. Retrieved from http:// www.apadivisions.org/division-30/about/index.aspx

Aristotle (1963). Metaphysics, Logic, Physics, Psychology, Ethics, Politics, Poetics. In The Philosophy of Aristotle. Translated by J.L. Creed \& A.E. Wardman. New York: A Mentor Book.

Aristotle (1976). The Nicomachean Ethics. Translated by J.A.K. Thomson. Middlesex: Penguin Books.

Aristotle. (1986). De Anima: On the Soul. Transl. by Hugh Lawson-Tancred, London: Penguin Books. [Kindle version 1.12.4 (41014)] Retrieved from amazon.com

Aristotle. (2007). The Metaphysics. Transl. by John H. McMahon, New York: Dover Publications. Retrieved from play.google.com

Askitopoulou, H., Konsolaki, E., Ramoutsaki, I.A., \& Anastassaki, M. (2002). Surgical cures under sleep induction in the Asclepieion of Epidauros, International Congress Series, 1242, 11-17, Retrieved from http:// dx.doi.org/10.1016/S0531-5131 (02)00717-3 (//www.sciencedirect.com/science/article/pii/ S0531513102007173)

Astin, J.H., Shapiro, S.L., Eisenberg, D.M., \& Forys, K.L. (2003). Mind-Body Medicine: State of the Science, Implications for Practice, Journal of the American Board of Family Medicine, March-April 2003, 16 (2), 131-147 doi: 10.3122/jabfm.16.2.131

Australian Psychological Society (APS). (2016). Ethical guidelines on the teaching and use of hypnosis. Retrieved from https://www.psychology.org.au/Assets/Files/EGHypnosis.pdf

Bahalii, D. (1992). Ukrainian travelling philosopher, Hryhorii Skovoroda. Kyiv: Oriy.

Bakker, J. I. (2010). Ontology. In A. J. Mills, G. Durepos \& E. Wiebe (Eds.), Encyclopedia of Case Study Research (pp. 629-632). Thousand Oaks, CA: Sage Publications.

Barabasz, A. F. \& Watkins J.G. (2005). Hypnotherapeutic Techniques 2E, New York: Brunner-Routledge.

Barabasz, A.F. \& Barabasz, M. (2015). The New APA Definition of Hypnosis: Spontaneous Hypnosis MIA, American Journal of Clinical Hypnosis, 57:4, 459-463, doi:10.1080/00029157.2015.1011507

Baxter, P., \& Jack, S. (2008). Qualitative case study methodology: Study design and implementation for novice researchers. The Qualitative Report, 13(4), 544-559. Retrieved from http://www.nova.edu

Beck J.S. (2011). Cognitive behavior therapy: Basics and beyond (2nd ed.). New York, NY: The Guilford Press.

Best, M. Butow, P., \& Olver, I. (2015). Do Patients want Doctors to talk about Spirituality? A Systematic Literature Review. Patient Education and Counselling, 98, 1320-1328. http://dx.doi.org/10.1016/j.pec.2015.04.017

Bilaniuk, P.B.T. (1994). An Introduction to the theological thought of Hryhorij Skovoroda. In R.H. Marshall, Jr. \& T.E. Bird Eds. (1994). Hyrhorij Savyи Skovoroda: An Anthology of critical articles. University of Alberta, Edmonton, Canada: Canadian Institute of Ukrainian Studies Press.

Bloomberg, L. D., \& Volpe, M. (2008). Completing Your Qualitative Dissertation: A Roadmap from Beginning to End. Thousand Oaks, CA: SAGE Publications.

Braid, J. (1843). Neurypnology, or the rationale of nervous sleep considered in relation to animal magnetism: Illustrated by numerous cases of its successful application in the relief and cure of disease. London: Churchill.

Braid, R. (2008). Our Healing: An Empirical Study of the Interrelationship Between Therapeutic Intervention and Spiritual Intervention in a Social Work Private Practice. (PhD Dissertation). La Trobe University.

Breitbart, W. (2001). Spirituality and meaning in supportive care: spirituality- and meaning-centered group psychotherapy interventions in advanced cancer. Supportive Care in Cancer. Springer-Verlag. doi:10.1007/ s005200100289

Brŭmault-Phillips, S., Olson, J., Brett-MacLean, P., Puchalski, C.M. (2015). Integrating Spirituality as a Key Component of Patient Care. Religions, 6, 476-498; doi:10.3390/rel6020476

Brown, D.P. \& Fromm, E. (1986). Hypnotherapy and hypnoanalysis. Hillsdale, New Jersey: Lawrence Erlbaum Publishers.

Brugnoli, M.P. (2016). Clinical hypnosis for palliative 
care in severe chronic diseases: a review and the procedures for relieving physical, psychological and spiritual symptoms. Ann Palliat Med, 5(4):280-297, doi:10.21037/ apm.2016.09.04

Campbell, L. (1997). Good and proper: considering ethics in practice research. Australian Social Work. 50(4), 29-36.

Carey, T. A., \& Mullan, R. J. (2004). What is Socratic questioning? Psychotherapy: Theory, Research, Practice, Training, 41(3), 217-226. Retrieved from http:// search.proquest.com

Childs, C.Y. (2014). Exploratory Factor Analysis of the Spiritual Wellness Inventory. PhD Dissertation. Cleveland: Cleveland State University.

Cobb, M., Rumbold, B. \& Puchalski, C.M. (2014). The future of spirituality and healthcare. In M. Cobb, C.M. Puchalski \& B. Rumbold (Eds.). Oxford Textbook of Spirituality and Healthcare. Oxford: Oxford University Press.

Corey, G. (2013). Theory and Practice of Counselling and Psychotherapy. ( $9^{\text {th }}$ ed.). Belmont. CA: Brooks/Cole, Cengage Learning.

Corsini, R.J. \& Wedding, D. (1989). Current Psychotherapies. (4th ed.). Itasca, Illinois: F.E. Peacock Publishers, INC.

Creswell, J.W. (2014). Research design: Qualitative, Quantitative, and Mixed-Method Approaches. Thousand Oaks, CA: Sage Publications, Inc. 4th ed. [Kindle version 1.12.4 (41014)] Retrieved from amazon.com.

Dallos, R. \& Vetere, A. (2005). Researching Psychotherapy and Counselling. Berkshire: Open University Press.

Daniels, C. \& Fitzpatrick, M. (2013). Integrating Spirituality into Counselling and

Psychotherapy: Theoretical and Clinical Perspectives. Canadian Journal of Counselling and Psychotherapy. 47(3), 315-341.

Davis, E., (2015), Literature review of the evidence-base for the effectiveness of hypnotherapy. Melbourne: PACFA. Retrieved from http://www.pacfa.org.au

Descartes, R. (1972). Two Meditations. In J.H. Randall, J. Buchler \& E.U. Shirk (eds.) Readings in Philosophy. New York: Barnes \& Noble

Descartes, R. (1980). Discourse on Method and the Meditations. London: Penguin Classics.

Dolan, L.M. (2009). An integrated approach to the psychotherapeutic treatment of vaginismus incorporating hypnosuggestion and hypnoanalysis, Australian Journal of Clinical \& Experimental Hypnosis, 37(1) 60-73

Dolan, L. M. (2000). The treatment of irritable bowel syndrome: A holistic approach. (Master's Dissertation). Johannesburg: University of Johannesburg.

D’Souza, R. \& George, K. (2006). Spirituality, religion and psychiatry: its application to clinical practice. Australasian Psychiatry, 14(4), doi:10.1111/j.14401665.2006.02314.x

Duncan, B.L., Miller, S.D., Wampold, B.E., \& Hubble, M.A. (Eds.) (2010). The Heart and Soul of Change: Delivering what works in Therapy. Washington, DC, USA: American Psychological Association.

Elkins, G.R., Barabasz, A.F., Council, J.R. \& Spiegel, D. (2015). Advancing Research and Practice: The Revised APA Division 30 Definition of Hypnosis, International Journal of Clinical and Experimental Hypnosis, 63:1, 1-9, doi: 10.1080/00207144.2014.961870

Elliott R, Bohart, A.C, Watson J.C. \& Greenberg L.S. (2011). Empathy. Psychotherapy, 48:43-9.

Engel, G. L. (2012). The need for a new medical model: A challenge for biomedicine. Psychodynamic Psychiatry, 40(3), 377-96. doi:http://dx.doi.org/ 101521 pdps 2012403377

Erickson, M.H. (1967). Advanced techniques of hypnosis and therapy. New York: Grune \& Stratton.

Erickson, M.H. (1980a). Ed. Ernest Rossi. The Nature of Hypnosis and Suggestion. The Collected Papers of Milton Erickson on Hypnosis, Volume I. New York: Irvington Publishers, INC.

Erickson, M.H. (1980b). Ed. Ernest Rossi. Hypnotic Alteration of Sensory, Perceptual and Psychophysical Processes. The Collected Papers of Milton Erickson on Hypnosis, Volume II. New York: Irvington Publishers, INC.

Erickson, M.H. (1980c). Ed. Ernest Rossi. Hypnotic Investigation of Psychodynamic Processes. The Collected Papers of Milton Erickson on Hypnosis, Volume III. New York: Irvington Publishers, INC.

Farber, B.A. \& Doolin, E.M. (2011). Positive regard. Psychotherapy, 48: 58-64.

Flammer, E. \& Alladin, A. (2007). The Efficacy of Hypnotherapy in the

Treatment of Psychosomatic Disorders: Meta-analytical Evidence, International Journal of Clinical \& Experimental Hypnosis, 55:3, 251-274, doi:10.1080/00207140701338696

Fizer, J. (1997). Skovoroda's and Socrates' concepts of self-cognition: A comparative view. Journal of Ukrainian Studies, 22(1), 65-73. Retrieved from http:// search.proquest.com

Forel, A. (1919). Der Hipnotismus oder die Suggestion und die Psychotherapie. Stuttgar: Ferdinand Enke.

Frankl, V. E. (1984). Man's Search for Meaning. New York: Washington Square Press.

Frankl, V.E. (1988). The Will to Meaning: Foundations and Applications of Logotherapy. New York: Meridian.

Freud, S. \& Breuer, J. (2004). Studies in hysteria. London: Penguin Books.

Freud, S. (1988). The Interpretation of dreams. London: Penguin Books.

Freud, S. (1943). A General Introduction to Psychoanalysis. New York: Garden City Publishing Company, Inc.

Frey, B.B., Daaleman, T.P. \& Peyton, V. (2005). Measuring a Dimension of Spirituality for Health Research: Validity of the Spiritual Index of Well-being. Research in Aging. 27(5), 556-577.

Gezundhajt, H. (2007). An evolution of the historical origins of hypnotism prior to the twentieth century: Between spirituality and subconscious. Contemporary Hypnosis 24(4): 178-194. doi:10.1002/ch.341

Gockel, A. (2011). Client Perspectives on Spirituality in the Therapeutic Relationship, The Humanistic Psychologist, 39:2, 154-168, doi:10.1080/ 08873267.2011.564959

Hall, C.S. \& Lindzey, G. (1957). Theories of Personality. New York: John Wiley \& Sons.

Hammond, D.C. (2013). A review of the history of hypnosis through the late $19^{\text {th }}$ century. American Journal 
of Clinical Hypnosis, 56, 174-191.

Harman, W.W. (1981). Rationale for Good Choosing, Journal of Humanistic psychology, 21(1), 5-12, Retrieved from http://journals.sagepub.com.ezproxy.une.edu.au/doi/ pdf/10.1177/002216788102100102

Harman, W.W. (1995). Through Western Eyes, Journal of Human Values, 1(1), 49-65, retrieved from http:// journals.sagepub.com.ezproxy.une.edu.au/doi/abs/ $10.1177 / 097168589500100106$

Hartman, D. \& Zimberoff, D. (2011). Hypnosis and Hypnotherapy in the Milieu of Integrative Medicine: Healing the Mind/Body/Spirit. Journal of Heart-Centered Therapies, 14(1), 41-75, Heart-Centered Therapies Association. Retrieved from http://cdn2.hubspot.net

Hдuser W, Hagl M, Schmierer A, Hansen E. (2016). The efficacy, safety and applications of medical hypnosis - a systematic review of meta-analyses. Dtsch Arztebl Int, 113, 289-96. doi:10.3238/arztebl.2016.0289

Hayes, S.C., Follett, V.M. \& Linehan, M.M. (2011). Mindfulness and Acceptance: Expanding the cognitivebehavioural tradition. New York: Guilford Press.

Hegel (2009). The Philosophy of History. Transl. by J. Sibree, Scotts Valley, CA: IAP. [Kindle version 1.12.4 (41014)] Retrieved from amazon.com.

Heidegger, M. (1962). Being and Time. Transl. by John Macquarrie \& Edward Robinson, Oxford: Blackwell Publications.

Helliwell, J., Layard, R. \& Sachs, J. (2015). World Happiness Report: Summary. Retrieved from http:// www.council.cmu.ac.th/uploadfile/file 150604114857.pdf

Herink, R. (Ed.). (1980). The Psychotherapy Handbook: The $A$ to $Z$ Guide to more than 250 different therapies in use today. New York: New American Library.

Hlywa, E. (1998). Pryncypy psychotherapii i hypnotherapy (Principles of psychotherapy and hypnotherapy). Sydney: Star Printery.

Hlywa, E. (2004). Vstup do psychotherapii [Introduction to psychotherapy]. Kyiv: National University, Ostroh Akademie

Hlywa, E. (2006). Ontolohichnyj obras ludyny $v$ tvorchosti Hryhorii Skovoroda (Ontological theory of personality based on the writings of Hryhorii Skovoroda). Kyiv: KMM, Ukrainian Akademie of Pedagogical Sciences.

Hlywa E. (2008a). Protracted Hypnotic Rest. Australian Journal of Clinical and Experimental Hypnosis, 36(1), 5063

Hlywa, E. (2008b). Spontaneous and Induced Abreaction, Australian Journal of Clinical \& Experimental Hypnosis, 36(2), 78-92

Hlywa, E. (2009). "Hypnosis and Client-Centred Therapy". Internal Security, (1), 61-68

Hlywa, E. (2013). Discover happiness within yourself. Sydney: Sova Books.

Hlywa, E. \& Dolan, L.M. (2010). A New Approach to the genesis of hypnosis: A gift of love and security, Australian Journal of Clinical \& Experimental Hypnosis, 38(1) 25-43.

Hlywa, E. \& Dolan, L.M. (2010-2011). Spirituality, Hypnosis and Psychotherapy: A New Perspective, Australian Journal of Clinical \& Experimental Hypnosis, 38(2)/39(1), 111-127.
Hlywa, E. \& Dolan, L.M. (2016). Hypnotherapeutic intervention into the depths of the human mind: The origins of internal trauma and its influence upon the human being. Australian Journal of Clinical \& Experimental Hypnosis, 41(1), 17-40.

Hubble, M.A. Duncan, B.L., Miller, S.D. \& Wampold, B.E. (2010). Introduction, In B.L. Duncan, S.D. Miller, B.E Wampold and M.A. Hubble, (Eds.). The Heart and Soul of Change: Delivering what works in Therapy. Washington, DC, USA: American Psychological Association.

International Bible Society. (1978). The Holy Bible, New International version. Grand Rapids, Michigan: Zondervan Bible Publishers.

Ivey, A.E., D'Andrea, M.J. \& Ivey, M.B. (2012). Theories of Counselling and Psychotherapy: A Multicultural Perspective. Los Angeles: Sage

James, W. (2011). The varieties of religious experience: A study in human nature. Cambridge, MA: Harvard University Press. (Original work published in 1902). [Kindle version 1.12.4 (41014)] Retrieved from amazon.com

Jamieson, G.A. (2007). Hypnosis and conscious states: the cognitive neuroscience perspective. Oxford: Oxford University Press.

Jaspers, K. (1971a). From reason and existence. In H.R. Blackham (Ed.). Reality, man and existence: Essential Works of Existentialism. New York: Bantam Books.

Jaspers, K. (1971b). Philosophy and science. In H.R. Blackham (Ed.). Reality, man and existence: Essential Works of Existentialism. New York: Bantam Books.

Jensen, M.P., Adachi, T., Tomem-Pires, C., Lee, J., Osman, Z.J., \& Mirom, J. (2015). Mechanisms of Hypnosis: Toward the Development of a Biopsychosocial Model, International Journal of Clinical and Experimental Hypnosis, 63:1, 34-75, doi:10.1080/00207144.2014.961875

Jung, C.G. (1916/2002). Psychology of the unconscious. (English ed. first published in 1916). Transl. By B.H. Hinkle. Mineola, New York: Dover Publications.

Jung, C.G. (1954). The development of personality. In G. Adler, M. Fordham, \& H. Read (Eds.), Collected Works (Vol. 11, Bollongen series XX, R.F.C. Hull, Trans.). New York: Pantheon.

Jung, C.G. (1958). The Spirit of Philosophy, in W. Burnett (Ed.). This is my philosophy, pp.114-167, London: Allen \& Unwin.

Jung, C.G. (1960). The Structure and dynamics of the Psyche. The collective works (Vol. 8). London: Routledge \& Kegan Paul.

Jung, C. G. (1974). Psychological reflections. London: Routledge \& Kegan Paul.

Jung, C.G. (2001). Modern man in search of a soul. New York: Harcourt.

Kallio, S. \& Revonsuo, A. (2003). Hypnotic phenomena and altered states of consciousness: A Multilevel framework of description and explanation. Contemporary Hypnosis, 20(3), 111-164.

Kant, I. (1958). Critique of Pure Reason. New York: The Modern Library.

Kierkegaard, S. (1972). Collection of Critical Essays. New York: Anchor Books.

Kierkegaard, S. (1974). Concluding unscientific postscript. Translated by D. E Swenson. Princeton: 
Princeton University.

Kleinhauz, M. (1991). Prolonged Hypnosis with Individualized Therapy. International Journal of Clinical \& Experimental Hypnosis, 34(2) 82-92.

Kodelja, Z. (2015) The voice of conscience in Rousseau's Emile. Ethics and Education, 10:2, 198-208, doi:10.1080/ 17449642.2015.1045211

Koenig, H. (2015). Religion, Spirituality, and Health: A Review and Update. Advances in Mind-Body Medicine, 29,(3).

Koenig, H. G., McCullough, M. E., \& Larson, D. B. (2001). Handbook of religion and health. New York, NY: Oxford University Press.

Kratochvil, S. (1970a). Prolonged Hypnosis and Sleep, American

Journal of Clinical Hypnosis, 12:4, 254-260, doi:10.1080/ 00029157.1970.10402060

Kratochvil, S. (1970b). Sleep hypnosis and waking hypnosis,

International Journal of Clinical \& Experimental Hypnosis, 18(1), 25-40, doi:

10.1080/00207147008415900

Kratochvil, S. \& Macdonald, H. (1972). Sleep in Hypnosis: A Pilot EEG Study,

American Journal of Clinical Hypnosis, 15:1, 29-37, doi:10.1080/00029157.1972.10402207

Kuriyama, K. (1968). Clinical applications of prolonged hypnosis in psychosomatic medicine. American Journal of Clinical Hypnosis, 11, 101-111.

Plante, T. G. (in press). Principles of incorporating spirituality into professional clinical practice. Practice Innovations.

London, P. (1962). Hypnosis in children: An experimental approach. International Journal of Clinical and Experimental Hypnosis, 10, 79-91.

Lynn, S.J., Green, J.P., Kirsch, I., Capafons, A., Lilienfeld, S.O., Laurence, J., \& Montgomery, G.H. (2015). Grounding Hypnosis in Science: The "New" APA Division 30 Definition of Hypnosis as a Step Backward. American Journal of Clinical Hypnosis, 57: 390-401. ISSN: 0002-

9157 print / 2160-0562 online

doi:10.1080/00029157.2015.1011472

Mackay, H. (2009). The Myth of an Australian Spirituality. St. George's Lectures, No. 16. Retrieved from https://www.perthcathedral.org/images/stories/ LectureSeries_no16.pdf

Marshall Jr., R.H. \& T.E. Bird, T.E. (1994) Eds. Hyrhorij

Savyи Skovoroda: An Anthology of critical articles. University of Alberta, Edmonton, Canada: Canadian Institute of Ukrainian Studies Press.

Marshall, B., Cardon, P., Poddar, A., \& Fontenot, R. (2013). Does Sample Size matter

in Qualitative research?: A review of qualitative interviews in IS research. Journal of Computer Information Systems, 54(1), 11-22, doi:10.1080/08874417.2013.11645667

Meares, A. (1967). The Space Between. International Journal of Clinical \& Experimental Hypnosis, XV(4), 156159.

Meares, A. (1972). A system of medical hypnosis. New York: Julian Press.

Meares, A. (1976). "Regression of Cancer After Intensive Meditation", The Medical Journal of Australia, 2, 184.
Meares, A. (1979). The Wealth Within. Melbourne: Hill of Content.

Meares, A. (1982-1983) A Form of Intensive Meditation Associated with the Regression of Cancer, American Journal of Clinical Hypnosis, 25(2-3), 114-121, doi:10.1080/ 00029157.1982.10404082

Mesmer, F.A. (1980). Mesmerism: A translation of the original medical and scientific writings of F.A. Mesmer, MD. Compiled and translated by G.J. Bloch. Los Altos, CA: William Kaufmann Inc.

Meilan, M. (2008). Hakomi Forum - Issue 19-20-21, Summer 2008. Retrieved from http:// www.hakomiinstitute.com/Forum/Issue19-21/ 3Restformatted2.pdf

Melbourne Academic Mindfulness Interest Group (2006). Mindfulness-based psychotherapies: a review of conceptual foundations, empirical evidence and practical considerations. Australian and New Zealand Journal of Psychiatry, 40(4), 285-294. Retrieved from http:// web.b.ebscohost.com

Meyerson, J. (2014). The Myth of Hypnosis: The Need for Remythification, International Journal of Clinical and Experimental Hypnosis, 62:3, 378-393, doi:10.1080/ 00207144.2014.901090

Miller, W.R. \& Thoresen, C.E. (2003). Spirituality, Religion and Health: An Emerging Research Field. American Psychologist, 58(1), 24-35. American Psychological Association. doi:10.1037/0003-066X.58.1.24

Morgan, A.H. \& Hilgard, E.R. (1973). Age differences in susceptibility to hypnosis. International Journal of Clinical and Experimental Hypnosis, 21, 78-85.

National Mental Health Commission (2014). The National Review of Mental Health Programmes and Services. Sydney: NMHC.

Pargament, K.I. (1999). The Psychology of Religion and Spirituality? Yes and no. International Journal for the Psychology of Religion, 9(1) 3-16. Retrieved from http:// web.b.ebscohost.com

Pargament, K.I. (2013). (Ed.). APA Handbook of Psychology, Religion and Spirituality: Vol.1. Context, Theory and Research. American Psychology Association. doi:10.1037/14045-001

Paxinos, G.S. (2016). Why Psychology lost its soul: Everything comes from the brain. APS College Paper, December 2016, Retrieved from http://createsend.com/t/ rD69A8F31814D47772540EF23F30FEDED

Plato. (1955). The Republic. (2 $2^{\text {nd }}$ ed. rev.). Transl. by D. Lee. Middlesex, England: Penguin Classics.

Plato. (1956). Protagoras and Meno. Transl. by W.K.C. Guthrie. London: Penguin Books.

Platonov, K. I. (1959). The word as a physiological and therapeutic factor. Moscow: Foreign Languages Publishing House.

Pols, H. (2013). Commentary: The Chelmsford scandal - reflection on physicians doing wrong. Australasian Psychiatry, 21(3), 216-219 doi:10.1177/1039856213486947

Porter, L.A. (2012). Crafting Practice in Trauma Therapy: A dialogical and relational engagement with ethics and poetic, sacred, spiritual and unnamed moments in therapeutic relationships. PhD Thesis. Armidale: University of New England.

Pretorius, H.G., Stuart, A.D., Dolan, L.M. \& De Bruin, 
K. (2001). A holistic approach to the treatment of Irritable Bowel Syndrome. SA Health/Gesondheid - Journal of Interdisciplinary Health Sciences, 6(4), 37-46.

Prochaska, J.O. \& Norcross, J.C. (2014). Systems of Psychotherapy: A Transtheoretical Analysis. $8^{\text {th }}$ ed. Stamford, CT: Cengage Learning.

Puchalski, C.M., Ferrell, B., Virani, R.... Sulmasy, D. (2009). Improving the quality of spiritual care as a dimension of palliative care: The report of the consensus conference. Journal of Palliative Medicine 12, 885-904.

Puchalski C. \& Romer A.L. (2000). Taking a spiritual history allows clinicians to understand patients more fully. Journal of Palliative Medicine 3:129-137.

Radovanиеviж, L. (2009). The tribute of the pioneer of hypnotherapy - Franz Anton Mesmer, MD, PhD in the history of psychotherapy and medicine. Acta MedicoHistorica Adriatica, 7(1), 49-60. Retrieved from http:// web.b.ebscohost.com

Rogers, C.R. (1942). Counselling and Psychotherapy. Cambridge, Mass: Houghton Mifflin.

Rogers, C.R (1951). Client-Centred Therapy. Boston: Houghton Mifflin.

Rogers, C.R. (1961). On Becoming a Person. Boston: Houghton Mifflin.

Rogers, C.R. (1986). Carl Rogers on the development of the person-centered approach. Person-Centered Review, 1(3), 257-259.

Rousseau, J.J. (1992). Discourse on the origin of inequality. First published in 1755. Translated by Donald A. Cress. Indiana: Hackett Publishing Company, Inc. [Kindle version 1.12.4 (41014)] Retrieved from amazon.com.

Ruysschaert, N. (2014). The Use of Hypnosis in Therapy to Increase Happiness, American Journal of Clinical Hypnosis, 56:3, 269-284,

doi:10.1080/00029157.2013.846845

Sartre, J. P. (1956). Being and Nothingness: An Essay on Phenomenological Ontology. New York: Philosophical Library.

Scherer, S. (1997). The narcissus: Skovoroda's "first-born son". Journal of Ukrainian Studies, 22(1), 51. Retrieved from http://search.proquest.com

Seaward, B. L. (2000). Stress and human spirituality 2000: At the cross roads of physics and metaphysics. Applied Psychophysiology and Biofeedback, 25, 241-246.

Seaward, B. L. (2015). Managing stress: Principle and strategies for health and wellbeing. Jones \& Bartlett Learning.

Selye, H. (1956). The stress of life. New York: McGrawHill.

Selye, H. (1972). Stress without distress. New York: Lipincott.

Shubin, D.H. (2012). Skovoroda: The world tried to catch me, but could not. A Biography and Analysis of the Itinerant Philosopher, Scholar and Christian Humanist, Grigori Savvich Skovoroda, and a Translation of selected Writings. USA: Shubin.

Skovoroda, H. S. (1972). Basic writings in two volumes. Kyiv: Naukova Dumka

Skovoroda, H. S. (1995). Discover human in yourself. Transl. by M. Kashuba, transl. of poetry by V.Voitovych, Lviv: Svit. (Григорій Сковорода; Пізнай в собі людину,
1995, Видавництво “Світ“, Львів. Переклад М. Кашуба та В. Войтович.

Skovoroda, H. (2005). A conversation among five travellers concerning life's true happiness*. Journal of Ukrainian Studies, 30(1), 1-45. Retrieved from http:// search.proquest.com

Soanes, C. \& Stevenson, A. (Eds). (2009). Concise Oxford English dictionary (11th ed., revised). Oxford: Oxford University Press.

Spiegel, H. \& Spiegel, D. (1978). Trance and Treatment: Clinical uses of hypnosis. New York: Basic Books.

Spiegel, H. \& Spiegel, D. (2004). Trance and Treatment: Clinical uses of hypnosis. ( $2^{\text {nd }}$ ed.). Washington DC: American Psychiatric Publishing, Inc.

Spiegel, H. \& Greenleaf, M. (2005). Commentary: Defining Hypnosis. American Journal of Clinical Hypnosis, 48:2-3,111-116.

St. Thomas Aquinas. (1967). Summa Theologia (Vol. 19). The Emotions, transl. by Eric D'Arcy, London: Blackfriars.

Theiler, S. \& Evans, B. (2016). The State of Hypnosis. APS College Paper, May 2016, Retrieved from http:// c clin . creat es end 1 . com/t/ V i ew Em a i $1 / \mathrm{r} /$ E0F71086B89644AB2540EF23F30FEDED

Tillich, P. (1952). The Courage to Be. London: Yale University Press.

Tillich, P. (1962). Existentialism and Psychotherapy: In H.M. Ruitenbeek (Ed.) Psychoanalysis and Existential Philosophy. New York: E. P. Dutton \& Co.

van Kaam, A.L. (1966). The Art of Existential Counselling: A New Perspective in Psychotherapy. WilkesBarr, Pennsylvania: Dimension Books.

van Kaam, A.L. (1969). Existential foundations of psychology. New York: Image Books.

van Kaam, A.L. (1975). In Search of Spiritual Identity. Denville, NJ: Dimension Books.

van Kaam, A.L. (2011). Muto, S. (Ed.). The Life Journey of a Joyful Man of God: The Autobiographical Memoirs of Adrian van Kaam. Eugene, Oregon: Resource Publications.

Viftrup, D.T., Hvidt, N.C. \& Buus, N. (2013). Spiritually and Religiously Integrated Group Psychotherapy: A Systematic Literature Review, Evidenced-Based Complimentary and Alternative Medicine. Article ID 274625, http://dx.doi.org/10.1155/2013/274265

Viljoen, H. (1989). Historical Overview of Psychological Thinking. In W.F. Meyer, C. Moore \& H.G. Viljoen (Eds.). Personality Theories from Freud to Frankl. Johannesburg: Lexicon Publishers.

Vontress, C. (1995). The philosophical foundations of the existential-humanistic perspective: A personal statement. Washington, DC: George Washington University.

Waldegrave, C. (2000). "Just Therapy" with Families and Communities. In G. Burford, \& J. Hudson (Eds.) Family Group Conferencing, New Directions in Community-Centred Child \& Family Practice. New York: Aldine De Gruyter, pp. 153-163.

Wampold, B.E. (2007). Psychotherapy: The humanistic (and effective) treatment. Am. Psychol., 62: 855-73.

Watkins, J.G. \& Barabasz, A. (2008). Advanced hypnotherapy. New York: Routledge 
Weisberg, M.B. (2008) 50 Years of Hypnosis in Medicine and Clinical Health Psychology: A Synthesis of Cultural Crosscurrents, American Journal of Clinical Hypnosis, 51:1, 13-27, doi:10.1080/00029157.2008.10401639

Wetterstrand, O. G. (1897). Hypnotism and its application to practical medicine. Translated by H.G. Peterson. New York: G. P. Putnam's sons. Retrieved from https://catalog.hathitrust.org/Record/100761569/Home

Wetterstrand, O.G. (1970). Practical teachings of the use of psychology in medicine. In M.M. Tinterow (1970). Hypnotism and Its Application to Practical Medicine, (pp. 513-543), Springfield, Illinois: Charles. C. Thomas.

Wolberg, L.R. (1964). Hypnoanalysis. New York: Grune \& Stratton.

Wolberg, L.R. (1948). Medical Hypnosis. New York: Grune \& Stratton.

Wolberg, L.R. (1967). The Technique of Psychotherapy. Part 1 and Part 2. ( $2^{\text {nd }}$ ed.). New York: Grune \& Stratton.

Wolcott, H. F. (2009). Writing Up Qualitative Research (3rd ed.). Thousand Oaks, CA: Sage Publications. [Kindle version 1.12.4 (41014)] Retrieved from amazon.com

Windholz, G. (1997). Retrieved from Ivan P. Pavlov: An overview of his life and psychological work

http://www.itma.vt.edu/courses/tel/resources/ windholz(1997)_pavlov.pdf

Yapko, M.D. (2003). Trancework: An Introduction to the practice of clinical hypnosis ( $3^{\text {rd }}$ ed.). New York: Brunner-Routledge.

Yin, R.K. (2014). Case Study Research: Designs \& Methods (5 ${ }^{\text {th }}$ ed.). Thousand Oaks, CA: Sage. [Kindle version 1.12.4 (41014)] Retrieved from amazon.com

Zakydalsky, T. (1994). Skovoroda's Moral Philosophy. In R.H. Marshall, Jr. \& T.E. Bird Eds. (1994). Hyrhorij Savyи Skovoroda: An Anthology of critical articles. University of Alberta, Edmonton, Canada: Canadian Institute of Ukrainian Studies Press.

Zwar, D. (1985). Doctor ahead of his times: The life of psychiatrist Dr Ainslie Meares. Richmond, Australia: Greenhouse Publications.

\section{АНОТАЦІЯ}

\section{Долан Лінда.}

Теорія внутрішнього голосу Григорія Сковороди та їі застосування в гіпнотерапевтичному відпочинку: клінічний підхід.

Український мислитель Григорій Сковорода (17221794) навчав, що остаточне щастя, здоров'я та винагорода залежать від усвідомлення людьми внутрішнього голосу, поваги та здійснення їх у своїх особистих цілях. Він підкреслив, що кожна особа є гідною людиною в очах Творця і постійно керується внутрішнім голосом або Святим Духом. Теорія Григорія Сковороди може вважатися надзвичайно актуальною для людей, які шукають духовних витоків у розумінні самих себе. Мислитель віднаходить внутрішній голос у низці різних контекстів. По суті він назвав внутрішній голос голосом Бога, голосом Творця, Святого Духа. Таким чином він розробив дві основні пропозиції. Поперше, з'ясував, що людина є духовною субстанцією. По-друге, відзначив, що вона здатна піддаватися впливу “земного пилу”. Однак він розглядав внут- рішній голос, дух як набагато більш потужний, ніж зовнішні впливи. Поняття духовності та його зв'язок 3 внутрішнім голосом ясно подані в теорії Григорія Сковороди i, тим самим, смислова картина духовності становить ключову концепцію його теорії.

На цьому тлі, слухаючи внутрішній голос, можна сприймати як унікальну релевантність духовності, що відіграє в гіпнотерапевтичному відпочинку значну роль, тому що це дозволяє пацієнту відображати себе зсередини, не піддаючись впливу жодного прямого зовнішнього джерела, наприклад, нав'язаних зовні рекомендацій, запитань до пацієнта або розповідей про те, що йому слід робити. Це виражає сутність даного дослідження, здійсненого після багатьох років клінічної практики, яка полягає в тому, що коли пацієнтам надають можливість почути власний голос чи то в спокійному гіпнотичному відпочинку, чи актуалізувати самісний “внутрішній діалог”, "розкаяння” або “споглядання”, вони можуть відображати і приймати особисті рішення. Вивчення теорії Григорія Сковороди про духовність $є$ цінним та унікальним внеском у розуміннєве поле гіпнозу, адже гіпноз значною мірою підвищує спроможності людини і дозволяє людям набувати досягнень у форматі власного самопізнання, використовуючи це для керівництва особистісним розвитком на своєму життєвому шляху.

\section{АННОТАЦИЯ}

\section{Долан Линда.}

Теория внутреннего голоса Григория Сковороды и ее применение в гипнотерапевтическом отдыхе: клинический подход.

Украинский мыслитель Григорий Сковорода (17221794) учил, что окончательное счастье, здоровье и вознаграждение зависят от осознания людьми внутреннего голоса, уважения и осуществления их в своих личных целях. Он подчеркнул, что каждое лицо является достойным человеком в глазах Творца и постоянно руководствуется внутренним голосом или Святым Духом. Теория Григория Сковороды может считаться чрезвычайно актуальной для людей, которые ищут духовных истоков в понимании самих себя. Мыслитель отыскивает внутренний голос в ряде различных контекстов. По сути он назвал внутренний голос голосом Бога, голосом Творца, Святого Духа. Таким образом он разработал два главных предложения. Во-первых, выяснил, что человек является духовной субстанцией. Во-вторых, отметил, что человек способен подвергаться воздействию “земной пыли”. Однако он рассматривал внутренний голос, дух как гораздо более мощный, чем внешние воздействия. Понятие духовности и его связь с внутренним голосом полно представлены в теории Григория Сковороды и, тем самым, смысловая картина духовности составляет ключевую концепцию его теории.

На этом фоне, слушая внутренний голос, можно воспринимать как уникальную релевантность духовности, которая играет в гипнотерапевтическом отдыхе значительную роль, так как это позволяет пациенту отображать себя изнутри, не поддаваясь влиянию ни одного прямого внешнего источника, например, на- 
вязанных извне рекомендаций, вопросов к пациенту или рассказов о том, что ему следует делать. Это выражает сущность данного исследования, проведенного после многих лет клинической практики, которая заключается в том, что когда пациентам дают возможность услышать собственный голос или в спокойном гипнотическом отдыхе, или актуализировать самостный “внутренний диалог”, “раскаяние” или "созерцание", они могут отображать и принимать личностные решения. Изучение теории Григория Сковороды о духовности является ценным и уникальным вкладом в поле понимания природы гипноза, ведь гипноз в значительной степени повышает способности человека и позволяет людям приобретать достижения в пределах самопознания, используя это для руководства личностным развитием на своем жизненном пути.

\section{ANNOTATION}

\section{Dolan Lynda.}

Hryhorri Skovoroda's theory on the inner voice and its application in hypnotherapeutic rest: an exploratory case study approach.

The Ukrainian philosopher, Hryhorri Skovoroda proposed that ultimate happiness, health and reward depend on a human being's awareness of one's inner voice and respect and implementation thereof in one's personal goals. He emphasized that every human being is a dignified person in the Creator's eyes and is constantly guided by the inner voice or the Holy Spirit. Skovoroda's theory can be considered to be highly relevant for human beings who are searching for spiritual entities in understanding themselves. Skovoroda referred to the inner voice in a number of different contexts. Fundamentally he referred to the inner voice as the voice of God, the voice of the Creator, the Holy Spirit. Thus he developed two core propositions. Firstly he found that the human being is a spiritual entity. Secondly, he found that the human being is capable of being influenced by "earthly dust" however he viewed the inner voice, the spirit, as much more powerful then external influences. The concept of spirituality and its relationship to the inner voice is clear in Skovoroda's theory and thus spirituality will form a key concept of this literature review.

Against this background, listening to one's inner voice can be seen to be uniquely relevant to the role spirituality plays in hypnotherapeutic rest because it allows the patient to reflect inwardly without being influenced by any direct external source, such as, imposing suggestions, asking the patient questions or telling them what to do. This forms the essence of my current study, where I have found after many years in clinical practice, that when patients are given the opportunity to listen to their own voice whether it be in quiet hypnotic rest or their own "inner dialogue", "reverie" or "contemplation", they can reflect and make their own decisions. It will be shown that an exploration of Skovoroda's theory on spirituality is a valuable and unique contribution to the field of hypnosis because hypnosis enhances human capacity to a great degree and thus enables human beings to reach within themselves for guidance in their path of life.

Рецензенти: д. психол. н., проф. Болтівець С.І. д. психол. н., проф. Москалець В.П.

Надійшла до редакції 31.08.2017. Підписана до друку 5.09 .2017

Український переклад статті див. на сторінці журналу в Інтернеті: psm2000.ucoz.va 